\title{
PENGARUH DINAMIKA SPASIAL SOSIAL EKONOMI PADA SUATU LANSKAP DAERAH ALIRAN SUNGAI (DAS) TERHADAP KEBERADAAN LANSKAP HUTAN (STUDI KASUS PADA DAS CITANDUY HULU DAN DAS CISEEL, JAWA BARAT) (Effect of Spatial Dynamics of Socio-Economic in the Watershed Landscape Toward The Existence of the Forest Landscape; Case Studies on Citanduy Hulu Watershed and Ciseel Watershed, West Java)
}

\author{
${ }^{1}$ Edy Junaidi, ${ }^{2}$ Retno Maryani \\ ${ }^{1}$ Balai Penelitian Kehutanan Ciamis, Jalan Ciamis-Banjar Km. 4 P.O. Box 5. Telp. 0265771352 \\ email: edy_jun2003@yahoo.com \\ ${ }^{2}$ Puslitbang Perubahan Iklim dan Kebijakan, Jl. Gunung Batu No.5 Bogor PO Box 272 Bogor 16167
}

Diterima 22 Januari 2013, direvisi 10 Mei 2013, disetujui 17 Mei 2013

ABSTRACT

Forest sustainability can not be separated from its surrounding environment, both ecological, economic and social. Management of forest resources that need to be done must be oriented toward ecosystem in totality. Therefore, the arrangement of land use forest plan need management at a landscape level. This study aims to investigate the interrelationship between socio-economic conditions of the people residing at watershed and environmental conditions that affect dynamics of forest landscape. The method for determining closeness of each characteristic (environmental and socio-economic) with the forest existence, uses Geographically Weighted Regression models (GWR), by looking at value of the correlation. Results showed that biophysical and socio-economic factors that have a strong correlation toward existence of the forest landscape in the Citanduy Hulu Watershed and the watershed Ciseel were: (i) rainfall, (ii) slope, (iii) erosion soil sensitivity, (iv) drainage density, (v) average slope, (vi) density and (vii) dependence on agricultural land.

Keywords: Biophysical, social-economic and forest lansdcape

\begin{abstract}
ABSTRAK
Kelestarian hutan tidak dapat dipisahkan dari kondisi lingkungan sekitarnya, baik yang bersifat ekologis, ekonomis maupun sosial. Pengelolaan sumberdaya hutan perlu dilakukan dengan berorientasi ekosistem secara keseluruhan. Oleh karenanya, rencana penataan tata guna hutan perlu pengelolaan di tingkat lanskap. Penelitian ini bertujuan untuk mengetahui adanya hubungan timbal balik antara kondisi sosial ekonomi masyarakat yang berada di dalam wilayah suatu DAS dengan kondisi lingkungan yang mempengaruhi terjadinya dinamika lanskap hutan. Metode untuk menentukan keeratan masing-masing karakteristik (lingkungan dan sosial-ekonomi) dengan keberadaan hutan, menggunakan model Geographically Weighted Regression (GWR) dengan melihat nilai korelasinya. Hasil penelitian menunjukkan bahwa faktor biofisik dan sosial ekonomi yang mempunyai korelasi yang kuat terhadap keberadaan lanskap hutan pada DAS Citanduy Hulu dan DAS Ciseel adalah (i) curah hujan, (ii) kelerengan, (iii) kepekaan tanah terhadap erosi, (iv) kerapatan drainase, (v) rata-rata lereng, (vi) kepadatan agraris dan (vii) ketegantungan terhadap lahan.
\end{abstract}

Kata kunci: Biofisik, sosial ekonomi dan lanskap hutan

\section{PENDAHULUAN}

Rencana tata ruang wilayah (RTRW) memberikan arahan spasial pengelolaan lahan yang ditetapkan sebagai kawasan hutan. Kementerian Kehutanan telah menyusun arahan spasial kawasan hutan di dalam dokumen Tata Guna Hutan
Kesepakatan (TGHK) yang memperhatikan hasil RTRW. Pada dokumen TGHK ditetapkan wilayah spasial kawasan hutan dan pengelolaan kawasan sesuai dengan fungsinya.

Pengelolaan hutan bertujuan untuk melestarikan sumberdaya hutan dan meningkatkan kesejahteraan masyarakat. Namun kenyataannya 
masih terdapat masyarakat miskin di dalam dan disekitar hutan. Kemiskinan masyarakat ini diduga memicu proses deforestasi dan degradasi hutan. Kelestarian hutan tidak dapat dipisahkan dari kondisi lingkungan sekitarnya, baik yang bersifat ekologis, ekonomis maupun sosial. Pengelolaan sumberdaya hutan perlu dilakukan dengan berorientasi ekosistem secara keseluruhan. Oleh karenanya, rencana tata guna hutan perlu dilakukan di tingkat lanskap.

Salah satu definisi lanskap dikemukakan Green et al. (1996). Lanskap merupakan konfigurasi khusus dari topografi, penutupan vegetasi, tata guna lahan dan pola pemukiman yang membatasi prosesproses alam dan budaya. Lanskap hutan dicirikan oleh karakteristiknya sebagai bentang alam yang didominasi oleh adanya faktor biotik hutan yang wilayahnya terdapat di pegunungan dan pantai. Lanskap hutan merupakan bentang alam yang didominasi oleh adanya hutan yang wilayahnya meliputi dari daerah hulu hingga ke bagian hilir. Lanskap hutan dapat dibatasi oleh suatu wilayah ekologi. Wilayah ekologi yang sering dipakai sebagai batas adalah Daerah Aliran Sungai (DAS). Lanskap DAS yang lebih komplek daripada lanskap hutan yang merupakan interaksi antara struktur penyusun dan fungsinya, menjadi alasan sebagai basis kajian lanskap hutan.

Pengelola hutan di Indonesia melalui pendekatan klasik mengklasifikasikan hutan sesuai dengan fungsinya, yaitu sebagai hutan produksi, hutan konservasi dan hutan lindung. Pengklasifikasian fungsi hutan ini hanya berdasarkan kondisi ekologis saja yaitu ketinggian tempat, kelerengan, jenis tanah dan curah hujan. Pendekatan pengelolaan semacam ini kurang tepat karena masih terjadi proses degradasi dan deforestasi hutan. Pendekatan pengelolaan ini dapat dilakukan perbaikan dengan menerapkan manajemen lanskap hutan yang memandang hutan sebagai suatu kesatuan fungsi, dan pengelolaannya tidak dapat dipisahkan dari tujuan untuk memenuhi kebutuhan yang beragam.

Manajemen lanskap hutan dapat menunjukkan agar proses perubahan yang dibentuk dan dipengaruhi kondisi hutan dalam skala luas dan dalam waktu yang panjang dapat dipahami oleh perencana pembangunan. Kajian lanskap hutan mencakup sebaran luas dan tutupan hutan serta sebaran fungsi hutan dan perubahannya, yang diakibatkan oleh adanya dinamika sosial-ekonomi dalam tataran spasial serta adanya dinamika lingkungan.

Penelitian ini bertujuan untuk mengetahui adanya hubungan timbal balik antara kondisi sosial ekonomi masyarakat yang berada di dalam wilayah suatu DAS dengan kondisi lingkungan yang mempengaruhi terjadinya dinamika lanskap hutan. Manfaat yang akan dihasilkan dari adanya penelitian ini adalah diperolehnya informasi kondisi sosial ekonomi masyarakat dan lingkungan yang mempengaruhi keberadaan hutan baik luas dan fungsinya, sebagai dasar bagi pengambil kebijakan untuk merumuskan regulasi pengelolaan hutan.

\section{METODE PENELITIAN}

\section{A. Lokasi dan Waktu Penelitian}

Penelitian ini dilaksanakan di 2 (dua) sub DAS yang berada di wilayah DAS Citanduy, yaitu sub DAS Citanduy Hulu dan sub DAS Ciseel. Untuk posisi administrasi dan posisi geografis lokasi penelitian dapat dilihat pada Gambar 1. Sub DAS Citanduy Hulu berada pada hulu DAS Citanduy yang memiliki karakteristik dengan kepadatan penduduk tinggi dan tekanan terhadap lahan yang berat, sedangkan DAS Ciseel berada pada bagian hilirDAS Citanduy yang memiliki karakteristik kepadatan penduduk sedang dengan tekanan terhadap lahan yang rendah.

\section{B. Metode Penelitian}

Tahapan kegiatan penelitian dibedakan menjadi 3 (tiga), yaitu tahapan survei, tahapan pengelompokan data dan tahapan analisa data. Kegiatan pada masing-masing tahapan sebagai berikut:

\section{Kegiatan Survei}

Kegiatan survei terdiri dari beberapa tahapan yang dibedakan sebagai berikut:

a. Persiapan

Kegiatan persiapan berupa kegiatan pengumpulan data sekunder yang dilakukan melalui studi pustaka yang meliputi laporanlaporan dan peta-peta dari instansi-instansi terkait. Jenis data yang dikumpulkan berupa data meteorologi (curah hujan, temperatur, radiasi matahari dan kecepatan angin), data SPAS (Stasiun Pengamatan Arus Sungai), data 


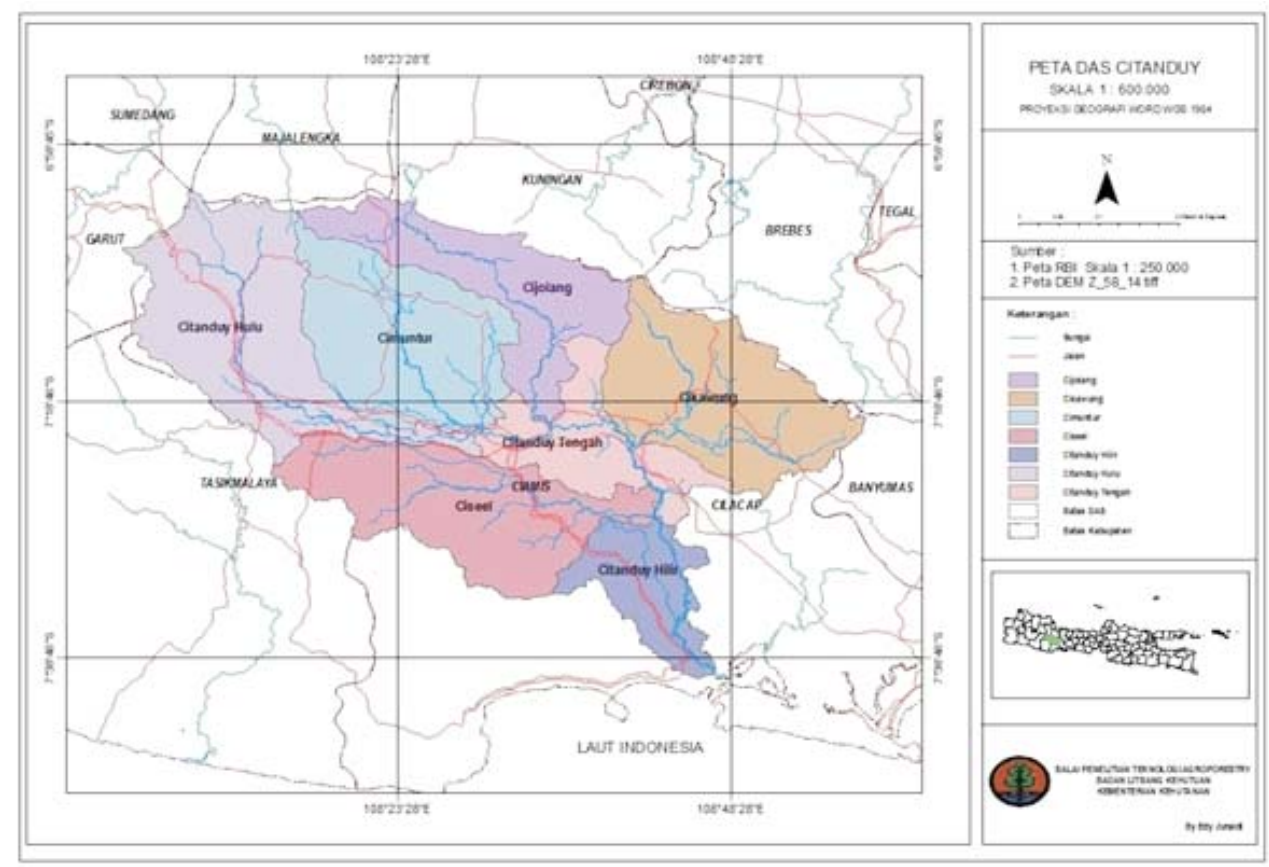

Gambar 1. Lokasi penelitian DAS Citanduy Hulu dan DAS Ciseel Figure 1. Study location at Citanduy Hulu Watershed and Ciseel Watershed

karakteristik lahan, data karakteristik tanah, data sosial - ekonomi, peta administrasi terbaru, peta tanah terbaru, peta penggunaan lahan (tahun 2003, 2006 dan 2009), peta TGHK dan peta RTRW Kabupaten (Garut, Ciamis dan Tasikmalaya).

b. Inventarisasi

Pada kegiatan ini dilakukan survei dan ground check di lapangan untuk mengumpulkan data primer pada lokasi sampel menggunakan pendekatan unit lahan. Penyusunan unit lahan dilakukan dengan cara membagi setiap sub-sub DAS ke dalam satuan peta yang mempunyai kesamaan parameter penggunaan lahan, lereng, curah hujan tahunan dan jenis tanah. Sampel pewakil ditentukan dengan caramembuat garis transek pada beberapa sub-sub DAS dimana garis tersebut dapat memotong sebagian terbesar dari unit lahan yang ada.

c. Pengelompokan data hasil persiapan dan inventarisasi

Data hasil kegiatan persiapan dan inventarisasi selanjutnya ditabulasi dalam bentuk tabel sesuai dengan kelompok karakteristik (lingkungan dan sosial-ekonomi) sebagimana ditunjukkan pada Tabel 1. Masing-masing kelompok data tersebut dibuat skoring menggunakan kriteria yang telah ada (Arsyad
(2006), Paimin et. al. (2006), Kepres No. 32 dan SK Mentan No. 837) (Lampiran 1). Kemudian dibuat peta sebaran spasial (peta tematik) yang akan digunakan pada tahapan analisis.

\section{Analisis Data}

Untuk menentukan keeratan masing-masing karakteristik (lingkungan dan sosial-ekonomi) dengan keberadaan hutan, digunakan model Geographically Weighted Regression (GWR). Tingkat keeratan antara masing-masing karakteristik dengan keberadaan hutan ditentukan berdasarkan besarnya koefisien korelasi (r). Makin tinggi nilai korelasinya berarti hubungan masingmasing karakteristik dengan keberadaan hutan makin erat.

Persamaan umum GWR yang dikembangkan oleh Fotheringham et. al.(2002) adalah

$$
\mathrm{y}_{\mathrm{i}}=\mathrm{a}_{0}\left(\mathrm{u}_{\mathrm{i}}, \mathrm{v}_{\mathrm{i}}\right)+\sum \mathrm{k} \mathrm{a} \mathrm{a}_{\mathrm{k}}\left(\mathrm{u}_{\mathrm{i}}, \mathrm{v}_{\mathrm{i}}\right) \text { xik }+\varepsilon_{\mathrm{i}}
$$

di mana $\mathrm{y}_{\mathrm{i}}$ adalah variabel bebas (luas hutan), $\mathrm{a}_{0}$ dan $\mathrm{a}_{\mathrm{k}}$ adalah variabel tak bebas berupa karakteristik lingkungan dan sosial-ekonomi, $\varepsilon_{\mathrm{i}}$ adalah nilai eror persamaan dan $\left(\mathrm{u}_{\mathrm{i}}, \mathrm{v}_{\mathrm{i}}\right)$ adalah koordinat masingmasing variabel. Perhitungan model GWR dilakukanmenggunakan bantuan software statistik spasial SAM 4. 
Tabel 1. Kelompok masing-masing data pada tiap-tiap karakteristik

Table 1. Each group of data on each characteristic

\begin{tabular}{|c|c|c|c|c|}
\hline No. & $\begin{array}{l}\text { Karakteristik } \\
\text { (Characteristic) }\end{array}$ & $\begin{array}{c}\text { Kelompok Data } \\
\text { (Data group) }\end{array}$ & $\begin{array}{r}\text { Jenis Data } \\
\text { (Data type) }\end{array}$ & $\begin{array}{c}\text { Teknik Inventarisasi } \\
\text { (Inventory techniques) }\end{array}$ \\
\hline \multirow[t]{16}{*}{1} & \multirow[t]{16}{*}{ Biofisik } & \multirow[t]{3}{*}{ Iklim } & Curah hujan tahunan (mm) & - Data hujan di DAS \\
\hline & & & $\begin{array}{l}\text { Hujan rata-rata harian maksimum } \\
(\mathrm{mm} / \text { hari) }\end{array}$ & - Data hujan 5 - 10 tahun terakhir \\
\hline & & & Evapotranspirasi aktual tahunan (mm) & $\begin{array}{l}\text { - Data iklim di DAS } \\
\text { - Metode perhitungan evapotranspirasi }\end{array}$ \\
\hline & & \multirow[t]{2}{*}{ Lahan } & Kelerengan lahan $(\%)$ & $\begin{array}{l}\text { - Peta topografi } \\
\text { - Program GIS }\end{array}$ \\
\hline & & & Bentuk lahan & - Peta geomorfologi \\
\hline & & \multirow[t]{6}{*}{ Tanah } & Kedalaman solum tanah (mm) & - Survei lahan \\
\hline & & & Batuan singkapan $(\%)$ & - Survei lahan \\
\hline & & & Drainase tanah & - Survei lahan \\
\hline & & & Permiabilitas ( & - Hasil analisa tanah \\
\hline & & & Erodibitas tanah & - Hasil analisa tanah \\
\hline & & & Hidrologi tanah & - Hasil analisa tanah \\
\hline & & \multirow[t]{4}{*}{ Morfometri DAS } & Bentuk DAS & - Peta DAS \\
\hline & & & Gradien sungai (\%) & $\begin{array}{l}\text { - Menggunakan metode Benson (1962) } \\
\alpha=(\mathrm{h} 85-\mathrm{h} 10)(0,75 \mathrm{LB}) \\
\text { Ket }: \mathrm{LB}=\text { panjang sungai } \\
\mathrm{h}=\text { elevasi }\end{array}$ \\
\hline & & & Kerapatan drainase $\left(\mathrm{km} / \mathrm{km}^{2}\right)$ & $\begin{array}{l}\text { - Rumus Dd }=\mathrm{L} / \mathrm{A} \\
\text { Ket }: \mathrm{L}=\text { panjang sungai } \\
\mathrm{A}=\text { luas DAS }\end{array}$ \\
\hline & & & Lereng rata-rata DAS (\%) & $\begin{array}{l}\text { - Peta topografi } \\
\text { - Program GIS }\end{array}$ \\
\hline & & Geologi & Jenis batuan & - Peta geologi \\
\hline \multirow[t]{8}{*}{2} & \multirow[t]{8}{*}{ Sosial - ekonomi } & \multirow[t]{5}{*}{ Sosial } & Rasio penduduk & - Data BPS \\
\hline & & & Kepadatan penduduk geografis (orang/ha) & - Data BPS \\
\hline & & & Kepadatan agraris (orang.ha) & - Data BPS \\
\hline & & & Tenaga kerja produktif & - Data BPS \\
\hline & & & Pengelompokan tenaga kerja & - Data BPS \\
\hline & & \multirow[t]{3}{*}{ Ekonomi } & Ketergantungan terhadap lahan (\%) & - Data BPS \\
\hline & & & Tingkat pendapatan & - Data BPS \\
\hline & & & Kegiatan dasar wilayah (LC) & - Data BPS \\
\hline
\end{tabular}

\section{HASIL DAN PEMBAHASAN}

\section{A. Kondisi Biofisik}

\section{DAS Citanduy Hulu}

DAS Citanduy Hulu terletak pada hulu DAS Citanduy yang secara geografi terletak pada $7^{\circ} 7^{\prime}-7^{\circ}$ $17^{\prime}$ LS dan $108^{\circ} 4^{\prime}-108^{\circ} 24^{\prime}$ BT. Luas DAS Citanduy Hulu sekitar $72.409,5$ ha. Panjang rata-rata sungai utama sekitar 7,4 km dengan gradien 1,02\% (agak rendah).

Pada penelitian ini DAS Citanduy Hulu dibagi menjadi 67 sub DAS. Pembagian ini dimaksudkan untuk mempermudah melakukan analisis lebih lanjut. Karakteristik masing-masing sub DAS dapat dilihat pada Lampiran 2.

Berdasarkan citra Landsat TM tahun 2009 terdapat 9 penggunaan lahan pada DAS Citanduy Hulu, yaitu belukar, hutan, pemukiman, pertanian semak, sawah, tambak, tubuh air, pertanian dan rawa. Luas masing-masing penggunaan lahan dapat dilihat pada Tabel 2, sedangkan letak penggunaan lahan secara spasial dapat dilihat pada Gambar 2.

Luasan penggunan lahan di DAS Citanduy Hulu yang berhutan sekitar 20,73\%, pertanian semak sekitar 25,61 \%, pertanian (pertanian dan sawah) sekitar 67,23\%, pemukiman sekitar 10,68 \% dan penggunaan lahan (belukar, tambak, tubuh air dan rawa) sekitar $1,36 \%$ dari total luas DAS.

a. Keadaan iklim

Peta sebaran spasial curah hujan tahunan selama 5 (lima) tahun yang berasal dari 6 (enam) stasiun curah hujan (stasiun curah hujan Kadipaten, Panjalu, Pagerageung, Ciamis, Cihonje dan Tasikmalaya) yang tersebar pada DAS Citanduy Hulu dapat dilihat pada Gambar 3A.

Berdasarkan Gambar 3 (A) dapat diketahui bahwa sebagian besar wilayah DAS Citanduy Hulu berada pada kisaran curah hujan lebih dari 2000 $\mathrm{mm} /$ tahun, yakni termasuk dalam kriteria tinggi, sedangkan luas wilayah DAS yang berada pada 
Tabel 2. Luas masing-masing penggunaan lahan di DAS Citanduy Hulu

Table 2. Area of each land use in Citanduy Hulu watershed

\begin{tabular}{|c|c|c|c|}
\hline No & $\begin{array}{l}\text { Penggunaan Lahan } \\
\text { (Land use) }\end{array}$ & $\begin{array}{l}\text { Luas }(\mathrm{Ha}) \\
(\text { Area })\end{array}$ & $\begin{array}{c}\text { Persentase }(\%) \\
\text { (Prosentage) }\end{array}$ \\
\hline 1 & Belukar & 553.8 & 0.76 \\
\hline 2 & Hutan poduksi & 887.9 & 1.23 \\
\hline 3 & Hutan terbatas & $4,974.3$ & 6.87 \\
\hline 4 & Hutan lindung & $9,146.7$ & 12.63 \\
\hline 5 & Pemukiman & $7,730.3$ & 10.68 \\
\hline 6 & Pertanian semak & $18,543.3$ & 25.61 \\
\hline 7 & Sawah & $20,676.1$ & 28.55 \\
\hline 8 & Tambak & 12.7 & 0.02 \\
\hline 9 & Tubuh air & 420.5 & 0.58 \\
\hline 10 & Pertanian & $9,462.5$ & 13.07 \\
\hline 11 & Rawa & 1.3 & 0.00 \\
\hline \multicolumn{2}{|r|}{ Tot a 1} & $72,409.5$ & 100 \\
\hline
\end{tabular}

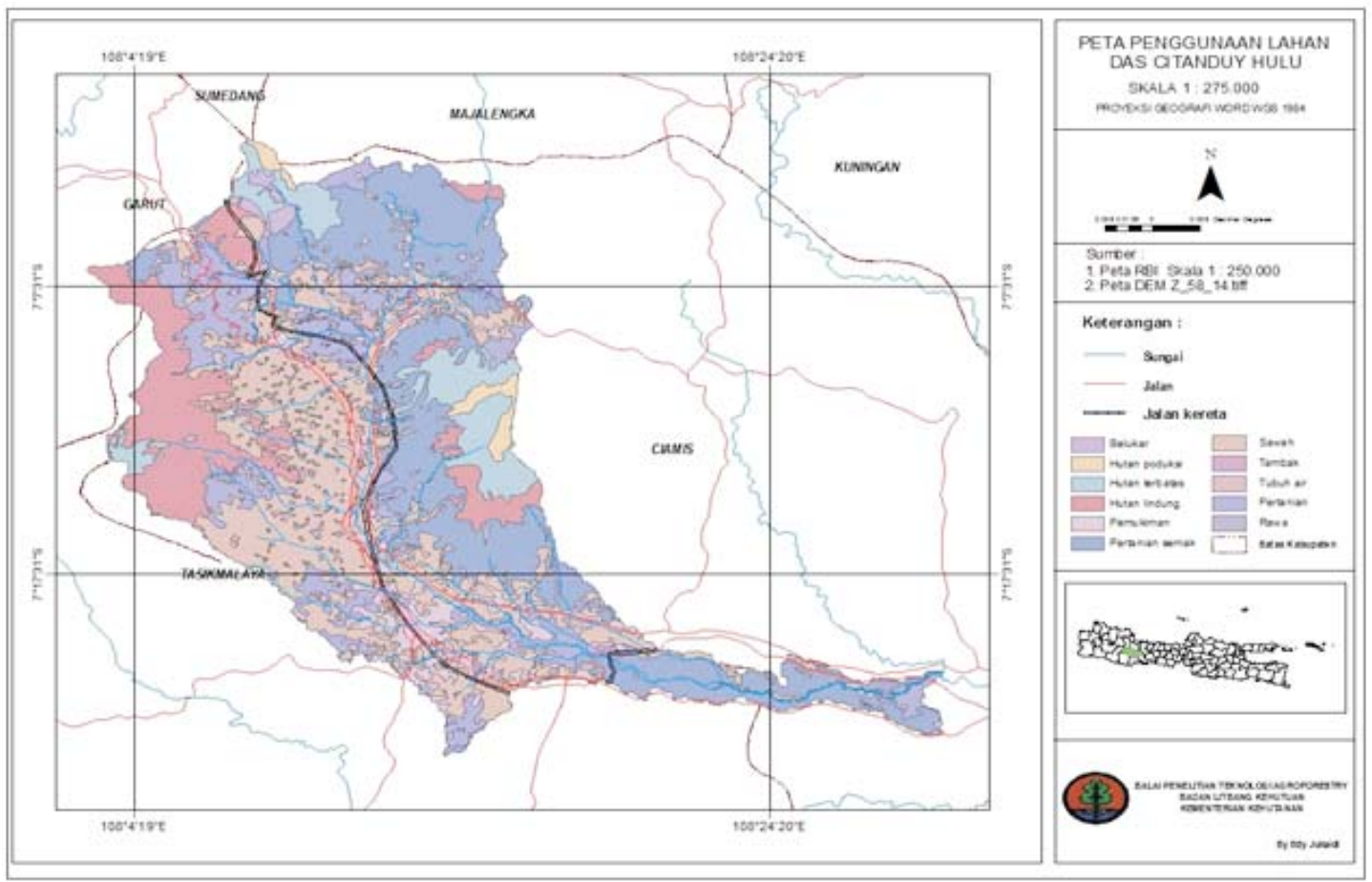

Gambar 2. Peta sebaran spasial penggunaan lahan di DAS Citanduy Hulu Figure 2. Map of spatial distribution land use in Citanduy Hulu watershed

kisaran curah hujan kurang dari $2000 \mathrm{~mm} /$ tahun hanya sekitar $12 \%$ dari luas DAS, tepatnya hanya disekitar hilir DAS Citanduy Hulu.

Gambar 3 (B) menunjukkan peta sebaran nilai evapotranspirasi aktual pada DAS Citanduy Hulu yang dihitung menggunakan metode Thornthwaite dari 4 (empat) stasiun iklim yang berada disekitar DAS Citanduy. Berdasarkan gambar tersebut diketahui bahwa sebagian besar DAS Citanduy
Hulu berada pada nilai aktual evapotranspirasi lebih dari $1000 \mathrm{~mm} /$ tahun, yakni termasuk kriteria sedang.

b. Keadaan geologi dan jenis tanah

Berdasarkan Peta Geologi, jenis batuan induk (geologi) yang terdapat di DAS Citanduy Hulu sebagian besar didominasi oleh campuran antara batuan andesit, basalt dan tefra berbutir halus (68 

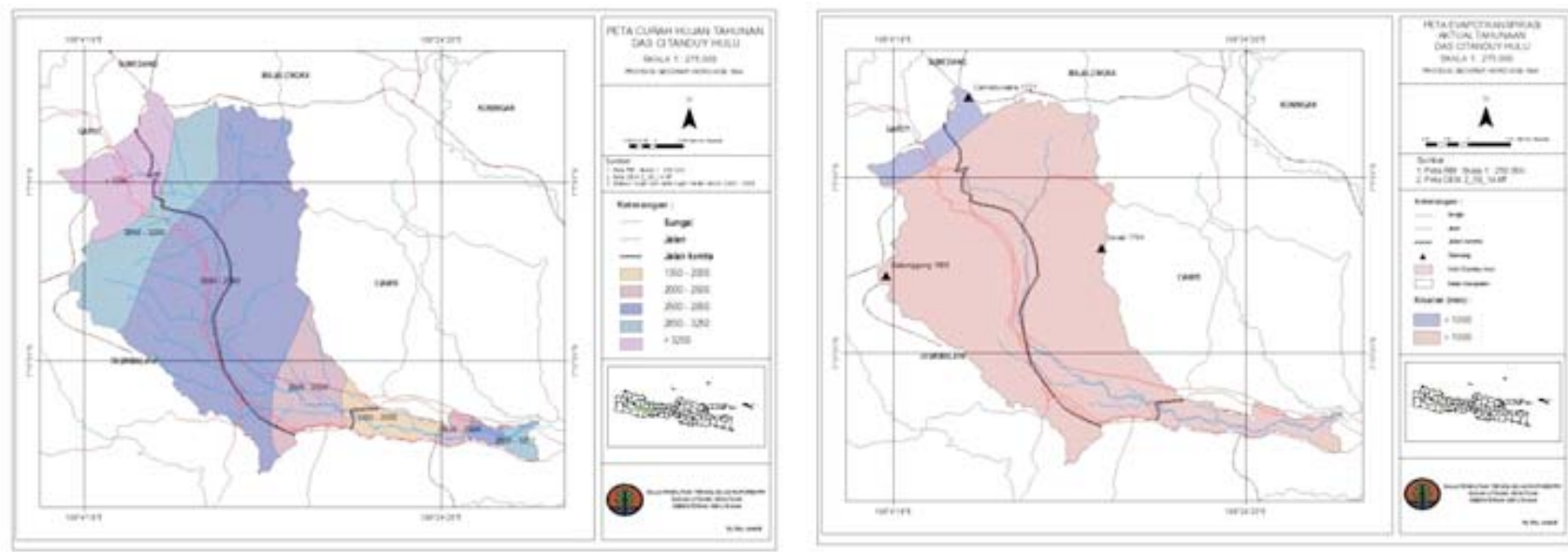

Gambar3. (A) Peta sebaran spasial curah hujan tahunan DAS Citanduy Hulu; (B) Peta sebaran spasial evapotranspirasi aktual tahunan DAS Citanduy Hulu

Figure 3. (A) Map spatial distribution of annual rainfall in Citanduy Hulu watershed; (B) Map spatial distribution of annual actual evapotranspiration in Citanduy Hulu watershed

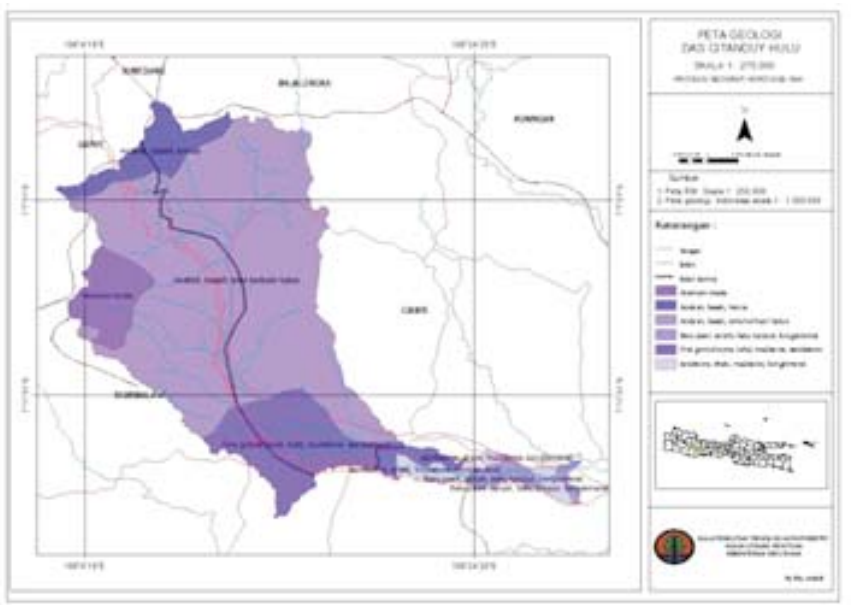

(A)

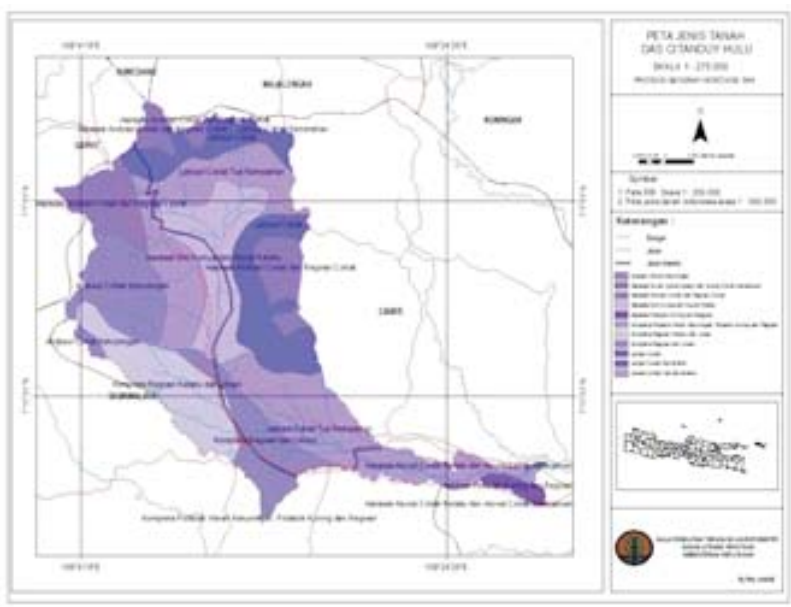

(B)

Gambar 4. (A) Peta geologi pada DAS Citanduy Hulu; (B) Peta jenis tanah Figure4. (B)Geological map of the Citanduy Hulu Watershed; (B) Map soil types)

$\%$ luas DAS). Pada Gambar 4 (A) terlihat sebaran jenis batuan di DAS Citanduy Hulu. Jenis batuan andesit, basalt dan tefra berbutir halus hampir tersebar merata pada bagian tengah dan hilir DAS Citanduy Hulu.

Terdapat 11 macam jenis tanah yang ada pada DAS Citanduy Hulu. Jenis tanah terluas sebarannya didominasi oleh latosal coklat kemerahan (30\%) dan latosal coklat $(16 \%)$, dimana keduanya merupakan jenis tanah yang peka erosi.Sebaran spasial jenis tanah pada DAS Citanduy Hulu dapat dilihat pada Gambar 4 (B). Tanah-tanah yang kurang peka erosi (jenis latosol) hampir mendominasi pada tengah dan hilir DAS, sedangkan tanah-tanah yang kurang peka terhadap erosi (tanah jenis andosol) berada pada hulu DAS. Peta sebaran kedalaman tanah, permiabilitas tanah, kandungan bahan organik tanah, dan nilai kepeka-an erosi tanah (nilai K) dapat dilihat pada Gambar 5. (A, B, C dan D).

Pada Gambar 6 (A) terlihat sebagian besar wilayah DAS Citanduy berada pada ketinggian 250 - $750 \mathrm{~m}$ dpl. Kisaran ketinggian ini hampir menempati lebih $50 \%$ luas DAS dan tersebar merata pada wilayah tengah dan hilir DAS.

Pada DAS Citanduy hulu terdapat 5 (lima) kelas kelerengan, yaitu kelas 0 - $8 \%$ (luas $40 \%$ dari luas 


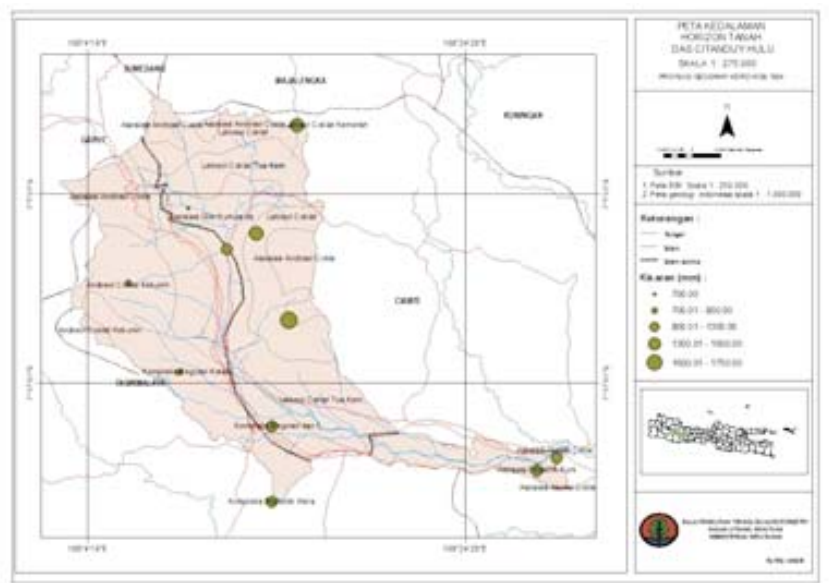

(A)

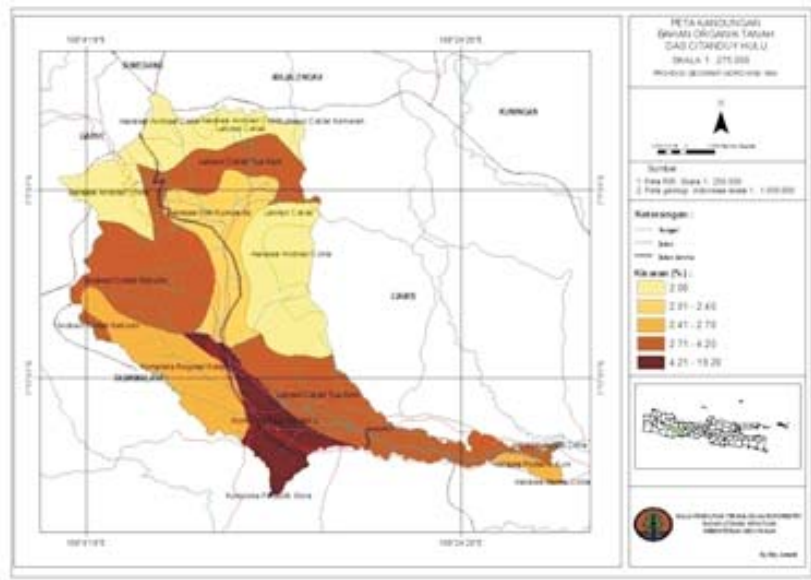

(C)

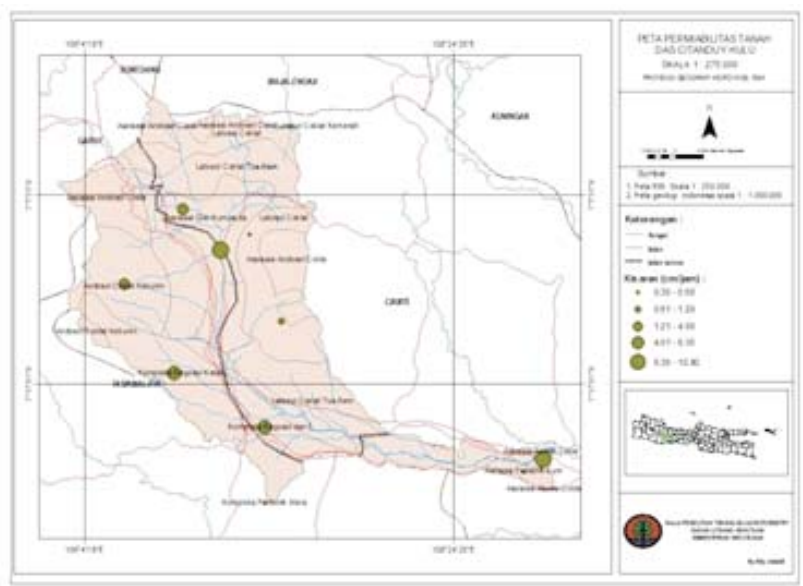

(B)

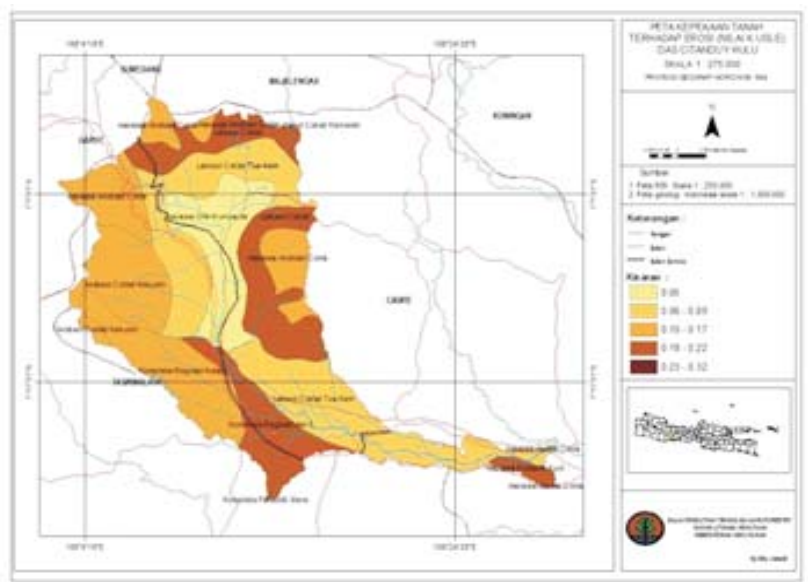

(D)

Gambar 5. Karakteristi masing-masing jenis tanah pada DAS Citanduy Hulu, (A) kedalaman horizon, (B) permiabilitas, (C) kandungan bahan organik dan (D) nilai kepekaan tanah terhadap erosi

Figure 5. Characteristic of each type of soil in the Citanduy Hulu Watershed, (A) depth of horizon, (B) permeability, (C) organic matter content and $(D)$ the value of erosion soil sensitivity

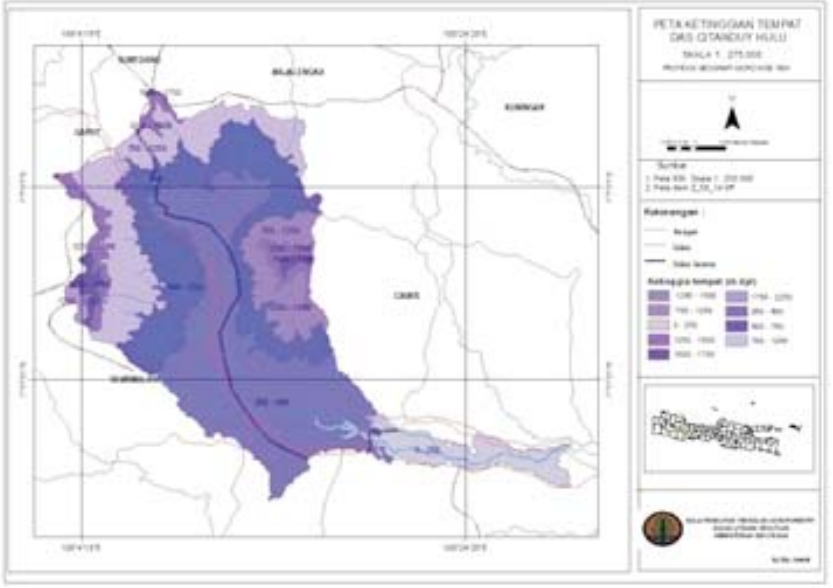

(A)

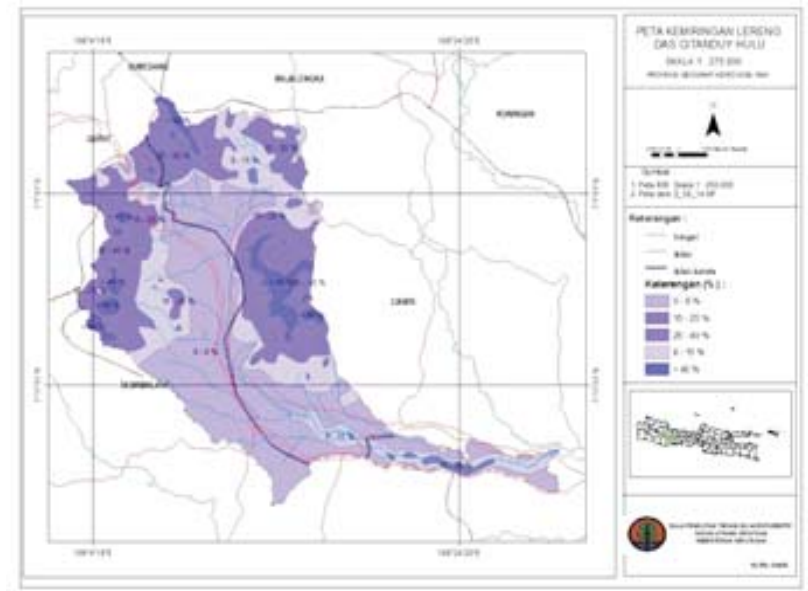

(B)

Gambar6. (A) Peta sebaran spasial ketinggian tempat pada DAS Citanduy Hulu; (B) Peta kemiringan lereng

Figur6. (A) Map of elevation ofspatial distribution in the Citanduy Hulu watershed; (B)Map of slope 
DAS), kelas $8-15 \%$ (22\% dari luas DAS), kelas 15 - $25 \%$ dengan luas $18 \%$ dari luas DAS, kelas 25 $40 \%$ mempunyai luas $15 \%$ dari luas DAS dan kelas $>40 \%$ dengan luas $5 \%$ dari luas DAS (Gambar 6 (B). Sebaran spasial kelerengan pada DAS Citanduy Hulu dapat dilihat pada Gambar 6 (B), dimana kelas kelerengan 0 - $8 \%$ tersebar pada DAS bagian tengah dan hilir, sedangkan kelas kelerengan yang lain terbesar merata pada hulu dan hilir DAS.

\section{DAS Ciseel}

Letak DAS Ciseel secara geografis, yaitu pada $7^{\circ}$ $37^{\prime}-7^{\circ} 17^{\prime}$ LS dan $108^{\circ} 24^{\prime}$ BT. DAS Ciseel yang terletak pada DAS Citanduy bagian hilir, berdasarkan hasil analisa dengan bantuan GIS mempunyai luas sekitar 61.905,1 Ha. Panjang ratarata sungai utama DAS Ciseel sekitar 7,1 km dengan gradien sungai agak rendah yakni $0,73 \%$.

Dengan menggunakan bantuan GIS, DAS Ciseel dalam penelitian ini dibagi menjadi 65 sub DAS dengan tujuan untuk mempermudah dalam melakukan analisis. Karakteristik masing-masing sub DAS dapat dilihat pada Lampiran 3.

Pada DAS Ciseel luas penggunaan lahan hutan (25\% luas DAS) dan yang bertajuk kayu (perkebunan dan pertanian semak) lebih luas dibandingkan areal untuk pertanian (14\% luas DAS). Gambar 7 menunjukkan sebaran spasial penggunaan lahan yang tersebar pada DAS Ciseel.

\section{a. Keadaan iklim}

Peta sebaran spasial curah hujan tahunan dianalisis berdasarkan data curah hujan selama 5 (lima) tahun. Data curah hujan berasal dari 5 (lima) stasiun curah hujan yaitu stasiun curah hujan Cineam, Pataruman, Sidamulih, Cikupa dan Cilacap yang tersebar pada DAS Ciseel.

Gambar 8 A menampilkan luasan dan persentase curah hujan pada wilayah DAS Ciseel. Pada peta terlihat bahwa sebagian besar wilayah DAS Ciseel berada pada kisaran curah hujan lebih besar $2000 \mathrm{~mm} /$ tahun (kriteria tinggi), dimana luasan wilayah tersebut meliputi $77 \%$ dari luas DAS Ciseel, sedangkan sisanya merupakan wilayah DAS yang mempunyai curah hujan lebih kecil 2000 $\mathrm{mm} /$ tahun, tepatnya disekitar hilir DAS Ciseel.

Wilayah DAS Ciseel berdasarkan klasifikasi iklim Mohr (1993) termasuk Golongan II yakni daerah agak basah dan berdasarkan klasifikasi iklim Schmidt - Fergusson (1951) termasuk tipe hujan golongan B yakni basah.

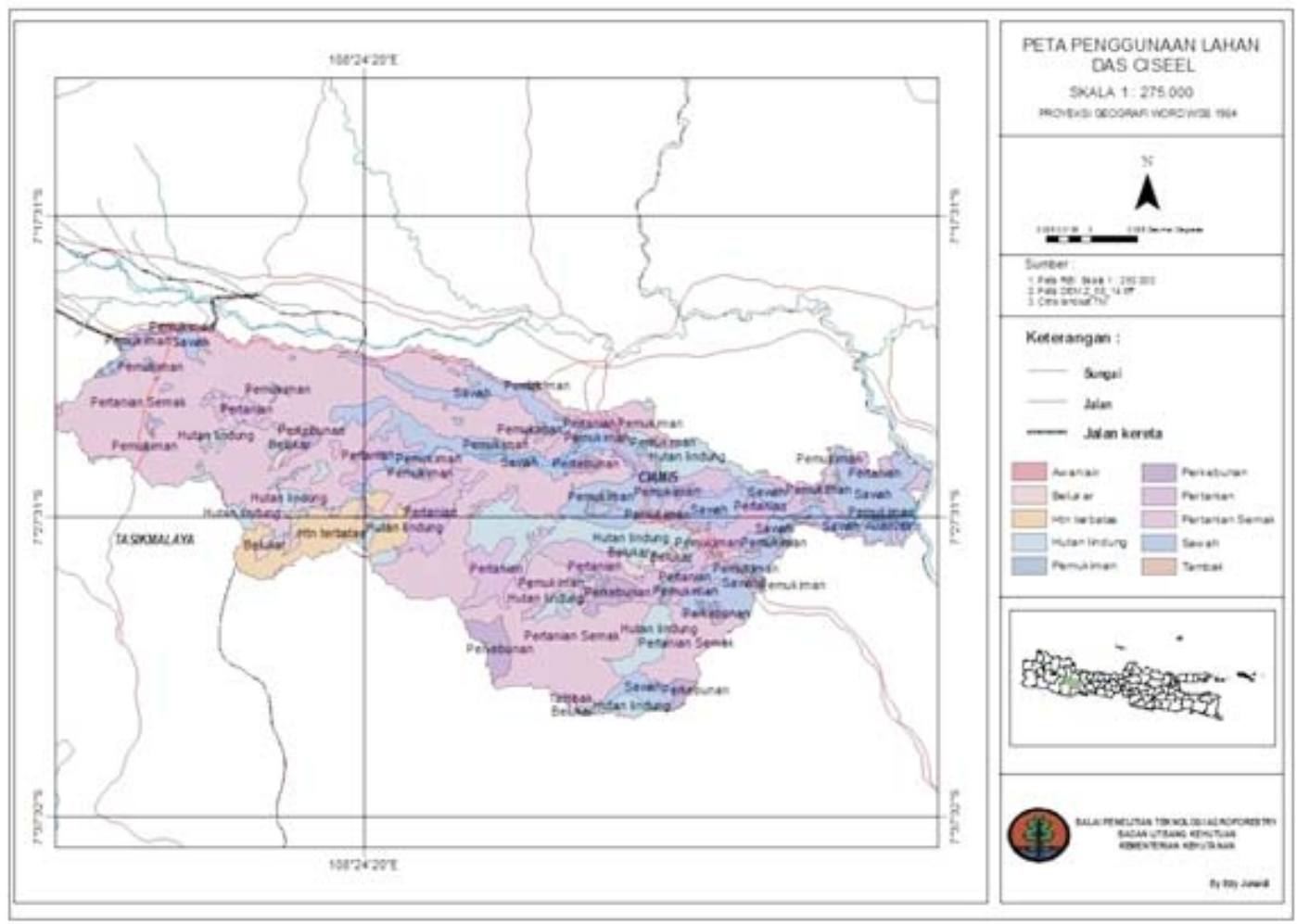

Gambar 7. Peta sebaran spasial penggunaan lahan di DAS Ciseel

Figure 7. Map of spatial distribution land use in Ciseel watershed 


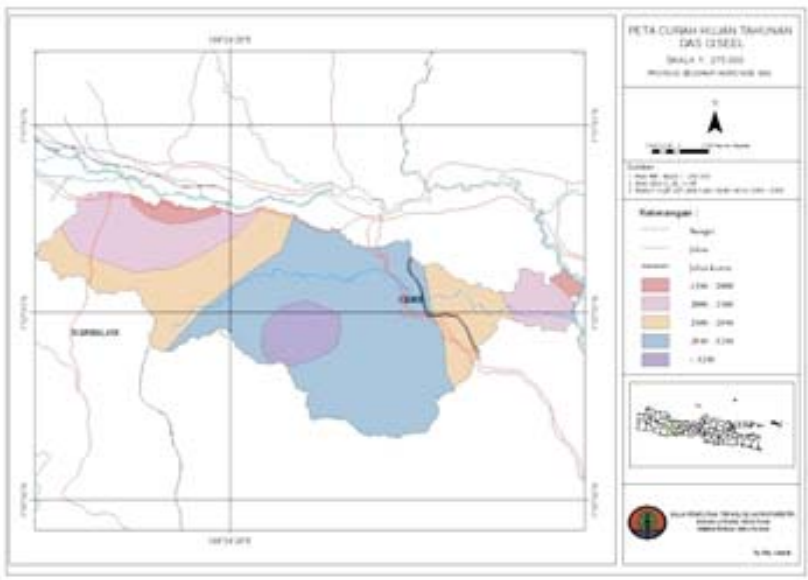

(A)

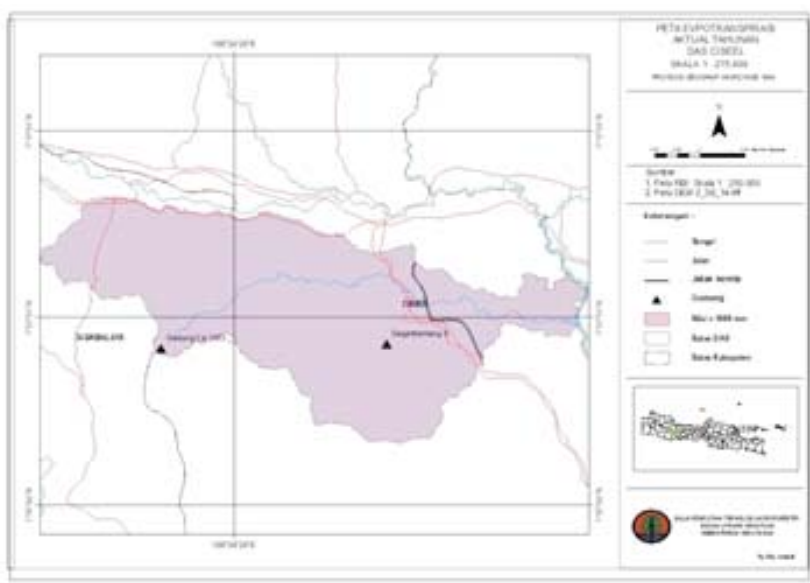

(B)

Gambar8. (A) Peta sebaran spasial curah hujan tahunan DAS Ciseel; (B) Peta sebaran spasial evapotranspirasi aktual tahunan DAS Ciseel

Figure 8. (A) Map spatial distribution of annual rainfall in Ciseel watershed; (B) Map spatial distribution of annual actual evapotranspiration in Ciseelwatershed

Gambar 8 B menunjukkan peta sebaran nilai evapotranspirasi aktual pada DAS Ciseel dengan menggunakan metode Thornthwaite dari 4 (empat) stasiun iklim yang berada disekitar DAS Citanduy. Peta tersebut menunjukkan bahwa seluruh DAS Ciseel berada pada nilai aktual evapotranspirasi lebih dari $1000 \mathrm{~mm} /$ tahun yakni termasuk kriteria sedang.

\section{b. Keadaan geologi dan jenis tanah}

Gambar 9 A menunjukkan sebaran spasial peta geologi yang terdapat di DAS Ciseel. Berdasarkan gambar tersebut diketahui bahwa sebagian besar jenis batuan induk pada DAS Ciseel didominasi oleh endapan aluvial muda yang menempati $45 \%$

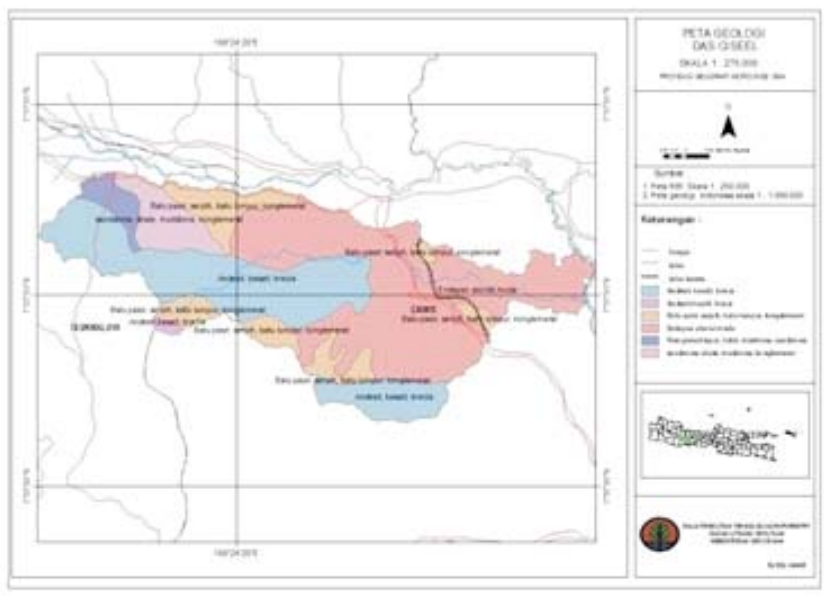

(A) dari luas DAS, serta batuan induk yang berasal dari andesit, basalt dan brecia yang menempati luas wilayah DAS sekitar $32 \%$. Untuk jenis batuan induk lain dapat dilihat pada Gambar 9 A.

Berdasarkan Gambar 9 A terlihat bahwa jenis bahan induk endapan aluvium tersebar merata pada bagian tengah dan hilir DAS Ciseel,sedangkan jenis batuan lain tersebar pada hulu DAS.

Terdapat 11 macam jenis tanah yang ada pada DAS Ciseel. Jenis tanah terluas sebarannya didominasi oleh komplek podsolik merah kekuningan, podsolik kuning dan regosol (28\%) serta komplek regosol dan litosol $(27 \%)$. Jenis komplek podsolik merah kekuningan, podsolik

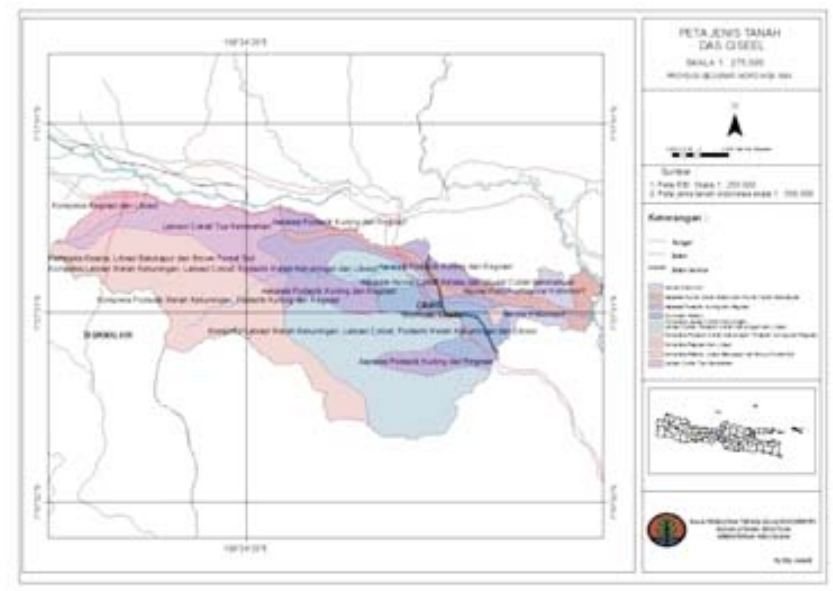

(B)

Gambar 9. (A) Peta geologi pada DAS Ciseel; (B) peta jenis tanah Figure 9. (A) Geological map of the Ciseel Watershed; (B) Map of soil types 


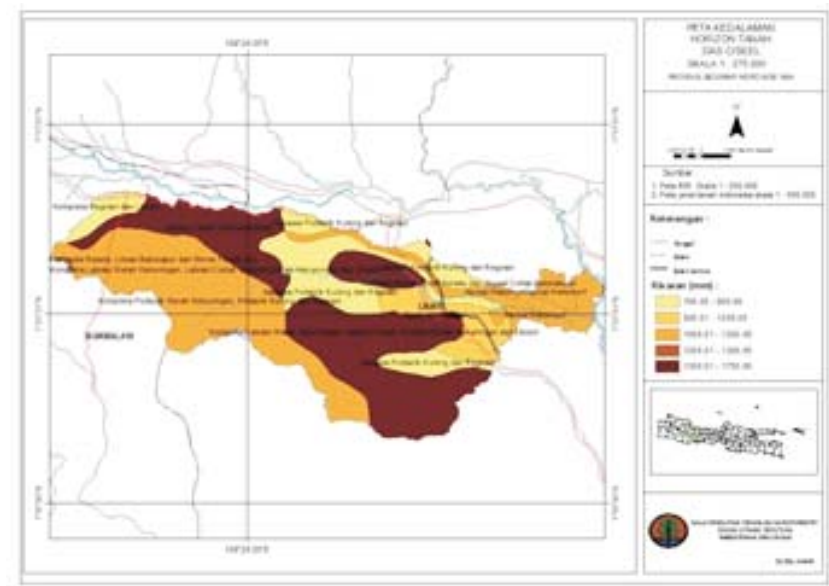

(A)

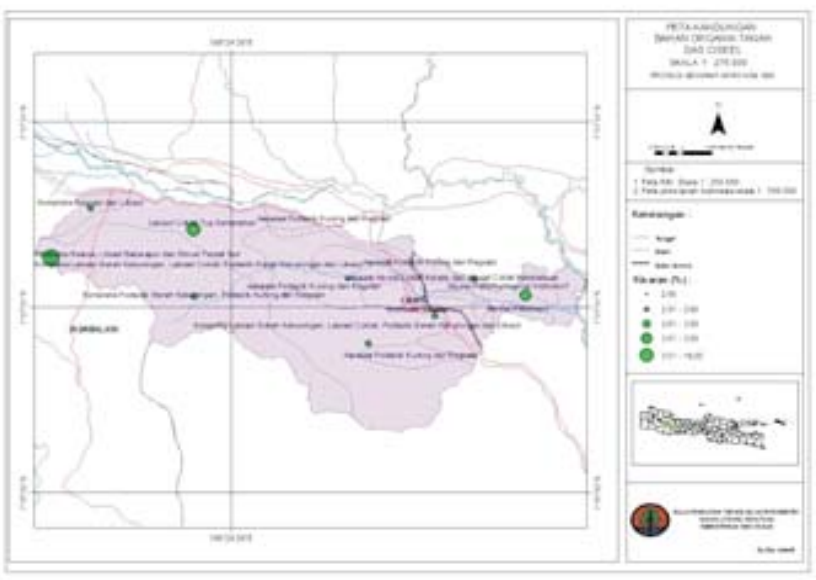

(C)

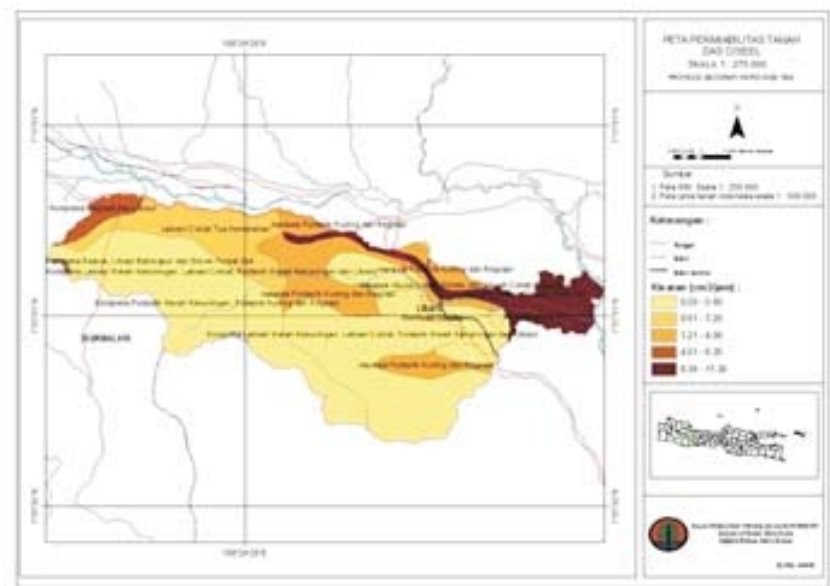

(B)

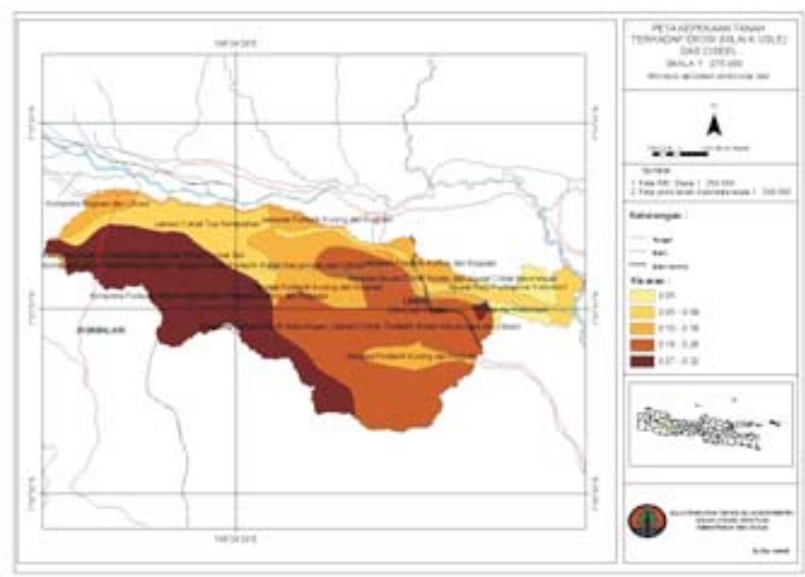

(D)

Gambar10. Karakteristik masing-masing jenis tanah pada DAS Ciseel, (A) kedalaman horizon, (B) permiabilitas, (C) kandungan bahan organik dan (D) nilai kepekaan tanah terhadap erosi

Figure 10. Characteristic of each type of soil in the Ciseel Watershed, (A) depth of horizon, (B) permeability, (C) organic matter content and (D) the value of erosion soil sensitivity

kuning dan regosol merupakan tanah peka erosi. Sebaran spasial jenis tanah pada DAS Ciseel dapat dilihat pada Gambar 9 B. Tanah-tanah yang peka erosi (komplek podsolik dan latosol) hampir mendomisi seluruh wilayah DAS, sedangkan tanahtanah yang kurang peka terhadap erosi seperti tanah jenis aluvial berada pada hilir DAS.

Peta sebaran kedalaman tanah, permiabilitas tanah, kandungan bahan organik tanah dan nilai kepekaan erosi tanah (nilai $\mathrm{K}$ ) dapat dilihat pada Gambar 10 A, B, C dan D.

c. Ketinggian tempat dan kelerengan DAS Ciseel

Pada Gambar 11 A terlihat sebagian besar wilayah DAS Ciseel berada pada ketinggian 0 - 250 $\mathrm{m}$ dpl. Kisaran ketinggian ini hampir menempati lebih $55 \%$ dari luas DAS dan tersebar merata pada wilayah tengah dan hilir DAS.

Pada DAS Ciseel terdapat 4 (empat) kelas kelerengan, yaitu kelas 0 - $8 \%$ (luas $37 \%$ dari luas DAS), kelas 8 - $15 \%$ (7\% dari luas DAS), kelas 15 - $25 \%$ dengan luas $47 \%$ dari luas DAS dan kelas 25 - $40 \%$ mempunyai luas $7 \%$ dari luas DAS (Gambar 12 B). Gambar 11 B menunjukkan sebaran spasial kelerengan pada DAS Ciseel. Kelas kelerengan 15 - $25 \%$ yang menempati sebagian besar kawasan DAS tersebar pada DAS bagian tengah, sedangkan kelas kelerengan yang lain terbesar merata pada hulu dan hilir DAS. 


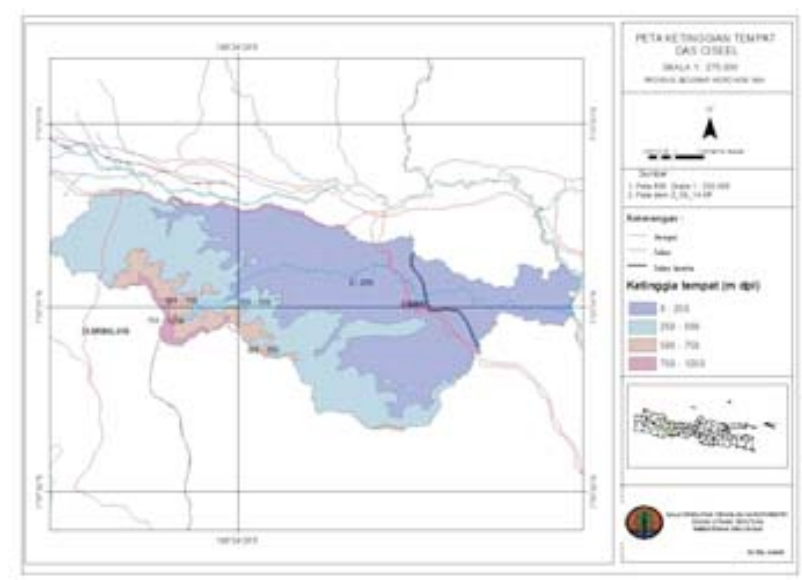

(A)

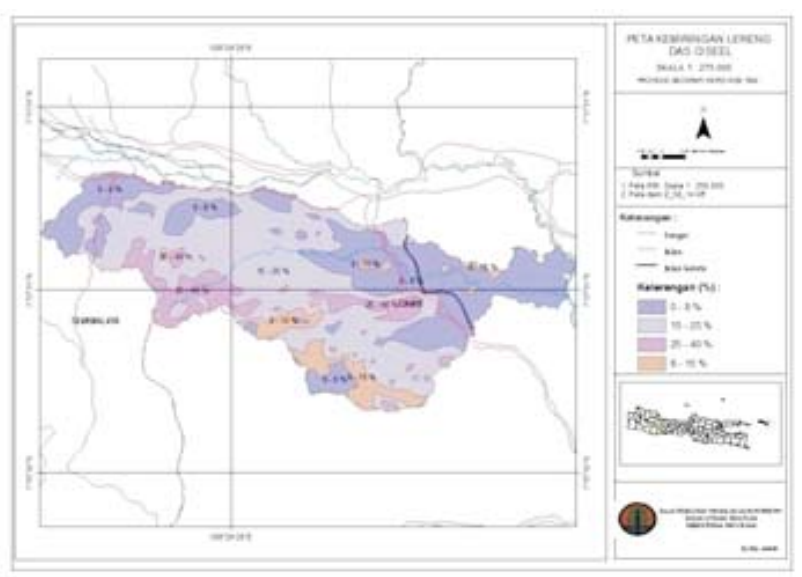

(B)

Gambar 11. (A) Peta sebaran spasial ketinggian tempat pada DAS Ciseel; (B) Peta kemiringan lereng Figure 11. Map of elevation ofspatial distribution in the Ciseel watershed; (B)Map of slope

\section{B. Kondisi Sosial dan Ekonomi}

\section{DAS Citanduy Hulu}

Secara Geografis, DAS Citanduy Hulu meliputi 5 (lima) wilayah administrasi kabupaten dan 1 (satu) kota yang berada di Provinsi Jawa Barat, yaitu Kabupaten Majalengka, Kabupaten Garut, Kabupaten Ciamis, Kabupaten Tasikmalaya, Kabupaten Sumedang dan Kota Tasikmalaya. Kabupaten Tasikmalaya terdapat 13 kecamatan yang masuk wilayah DAS Citanduy Hulu, sedangkan di Kota Tasikmalaya terdapat 6 (enam) kecamatan yang berada diDAS Citanduy Hulu. Untuk Kabupaten Ciamis, DAS Citanduy Hulu meliputi 12 kecamatan, untuk Kabupaten Garut meliputi 3 (tiga) kecamatan, Kabupaten Majalengka meliputi 2 (dua) kecamatan dan Kabupaten Sumedang hanya 1 (satu) kecamatan yang berada pada wilayah DAS Citanduy Hulu.

a. Kepadatan geografis DAS Citanduy Hulu

Kepadatan geografis mencerminkan jumlah penduduk yang mendiami suatu wilayah. Pada perhitungan kepadatan geografis dilakukan faktor koreksi luasan wilayah administrasi yang masuk dalam DAS Citanduy Hulu terhadap luasan wilayah administrasi yang sebenarnya.

Gambar 12 A menunjukkan sebaran spasial kepadatan geografis pada DAS Citanduy Hulu dalam kisaran range. Semakin tinggi nilai range menunjukkan kepadatan geografis wilayah tersebut makin tinggi. Kepadatan geografis untuk wilayah DAS Citanduy Hulu berada pada tengah dan hilir DAS. b. Sex rasio penduduk di DAS Citanduy Hulu

Sex rasio menunjukkan perbandingan antara jumlah penduduk pria dan wanita yang bermukim pada suatu wilayah. Semakin tinggi sex rasio suatu wilayah berarti jumlah penduduk laki-laki lebih banyak daripada penduduk wanita. Pada perhitungan sex rasio ini juga dilakukan faktor koreksi luasan wilayah administrasi yang masuk dalam DAS Citanduy Hulu terhadap luasan wilayah administrasi yang sebenarnya.

Pada peta sebaran sex rasio dalam bentuk dot matrik (Gambar 13 B) menunjukkan semakin besar dot, semakin besar pula nilai sex rasio. Pada DAS Citanduy Hulu sebaran sex rasio yang mempunyai nilai range besar hampir merata pada seluruh wilayah DAS.

\section{c. Kepadatan agraris DAS Citanduy Hulu}

Kepadatan agraris menunjukkan jumlah penduduk yang bekerja di sektor pertanian persatuan luas lahan pertanian. Pada perhitungan kepadatan agraris juga dilakukan faktor koreksi luasan wilayah administrasi yang masuk dalam DAS Citanduy Hulu dengan luasan wilayah administrasi sebenarnya.

Berdasarkan peta kepadatan agraris pada DAS Citanduy (Gambar 13 C), diketahui bahwa tingkat kepadatan agraris tinggi pada hampir seluruh wilayah DAS. Hal ini menunjukkan bahwa DAS Citanduy Hulu terjadi tekanan penduduk yang tinggi terhadap lahan pertanian.

d. Sebaran tenaga kerja DAS Citanduy Hulu

Salah satu faktor sosial lain yang dinilai pada penelitian ini adalah sebaran tenaga kerja. Semakin 


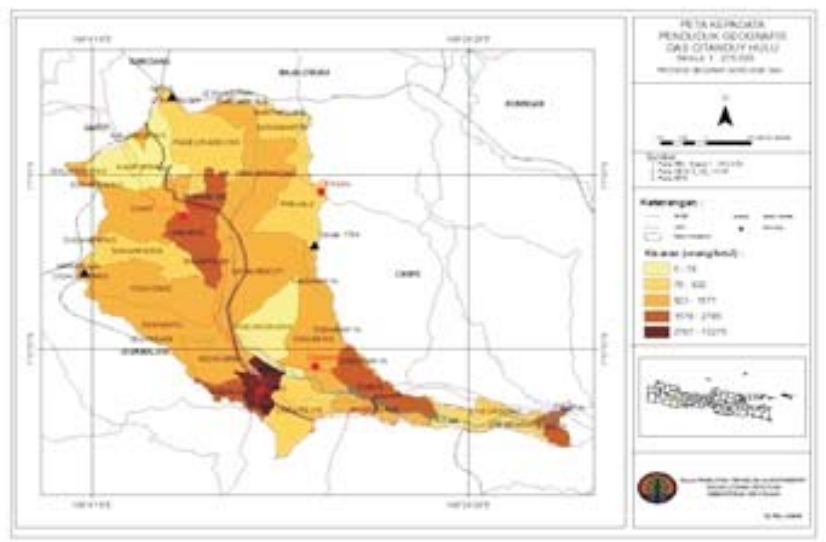

(A)

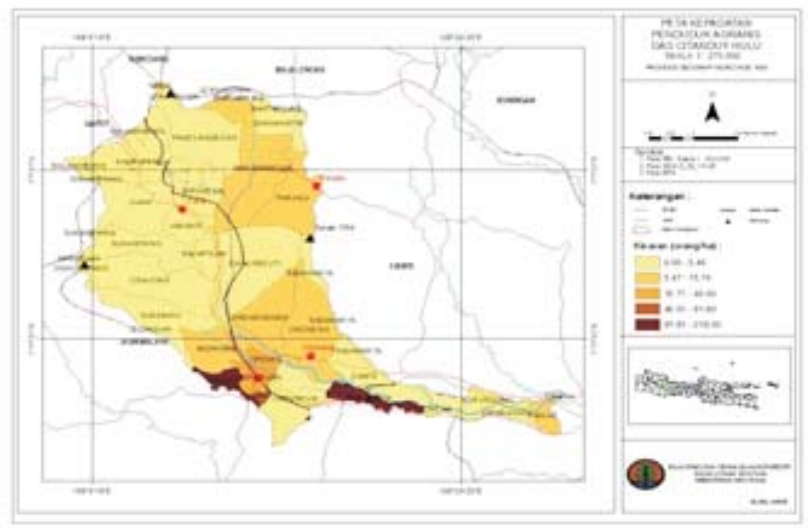

(C)

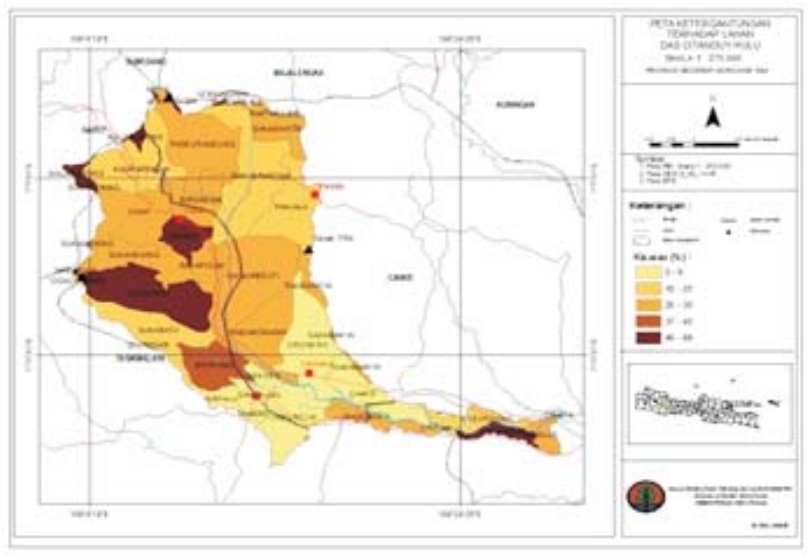

(E)

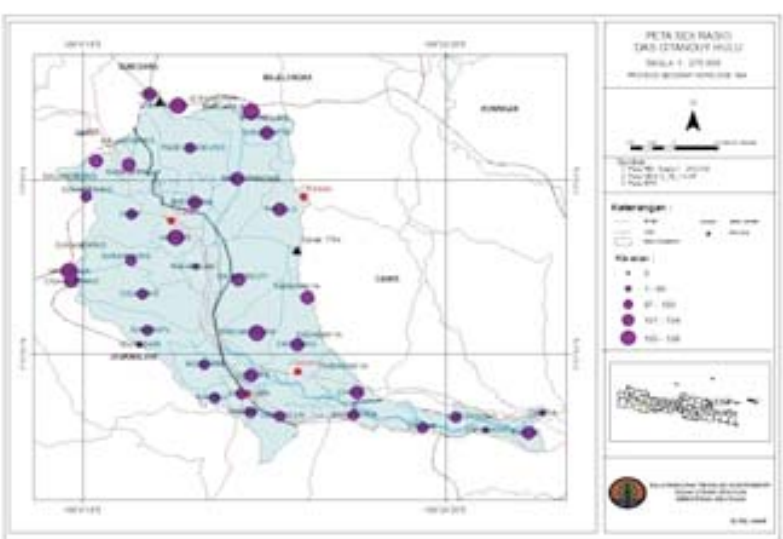

(B)

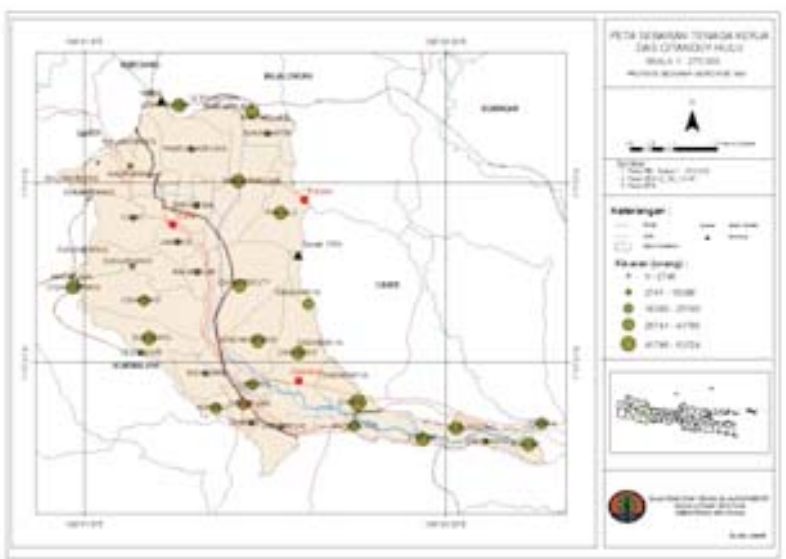

(D)

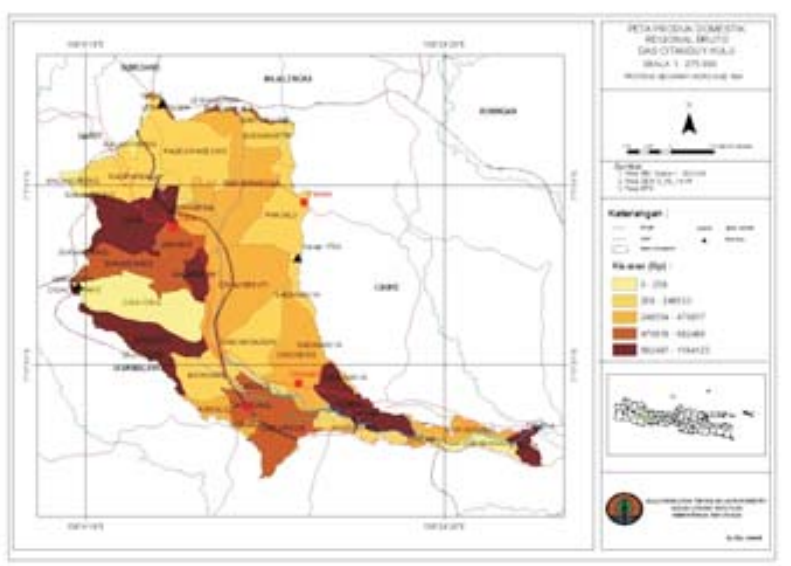

(F)

Gambar 12. DAS Citanduy Hulu (A) Peta sebaran kisaran kepadatan geografis; (B) Peta sebaran range rasio jenis kelamin; (C) Peta sebaran kepadatan agraris; (D) Peta sebaran tenaga kerja; (E) Peta sebaran ketergantungan terhadap lahan; $(\mathrm{F})$ Peta sebaran pendapatan

Figure 12. The Citanduy Hulu watershed (A) Distribution range map of Geographic density; (B) Distribution range map of sex ratios; (C) Distribution of Agricultural density; (D) Map of the Labor distribution; (E) Map of Reliance on land distribution; (F) Map of income distribution 
besar nilainya semakin besar tenaga kerja yang terdapat pada suatu wilayah,sehingga sebaran tenaga kerja dapat pula menggambarkan penumpukan tenaga kerja pada suatu wilayah. Perhitungan tenaga kerja juga menggunakan faktor koreksi luas lahan.

Berdasarkan Gambar 13 D diketahui bahwa pada DAS Citanduy Huluterjadi penumpukan tenaga kerja pada wilayah Kabupaten Ciamis. Hal ini menunjukkan jumlah tenaga kerja di Kabupaten Ciamis cukup besar, dengan range 41.796 -63.724.

e. Sebaran ketergantungan terhadap lahan pertanian DAS Citanduy Hulu

Nilai ketergantungan terhadap lahan pertanian merupakan salah satu kriteria yang dinilai untuk faktor ekonomi. Nilai ini menunjukkan perbandingan besarnya pendapatan pada sektor pertanian dibandingkan dengan pendapatan total. Semakin tinggi nilainya menunjukkan ketergantungan terhadap lahan pertanian makin besar. Perhitungan nilai ini juga menggunakan faktor koreksi perbandingan luas lahan.

Gambar 13 E, menunjukkan peta ketergantungan terhadap lahan di DAS Citanduy Hulu dimana sebaran nilai ini berada pada kisaran kurang dari $50 \%$, artinya berada pada kriteria rendah sampai sedang. Untuk wilayah Kabupaten Tasikmalaya mempunyai nilai kisaran sedang tinggi.

f. Sebaran pendapatan regional domestik bruto (PRDB) DAS Citanduy Hulu

Nilai sebaran PRDB digunakan sebagai kriteria faktor ekonomi yang lain pada penelitian ini. Nilai PRDB mencerminkan tingkat pendapatan suatu wilayah. Perhitungan nilai PRDP pada penelitian ini juga dilakukan koreksi dengan perbandingan luas wilayah administrasi.

Nilai pendapatan suatu wilayah administrasi yang mencerminkan pendapatan pada suatu DAS, pada penelitian ini digambarkan secara kisaran pada Gambar 13 F. Terlihat pada grafik pendapatan tertinggi berada disekitar wilayah DAS Citanduy Hulu bagian Hulu Barat, tepatnya di Kabupaten Tasikmalaya dan sekitarnya. Secara umum hasil perhitungan tingkat pendapatan perkecamatan berada pada kriteria rendah yakni lebih kecil dari pendapatan masing-masing kabupaten.

\section{DAS Ciseel}

Secara Geografis, DAS Ciseel berada pada wilayah administrasi 2 (dua) kabupaten dan 2 (dua) kota di Provinsi Jawa Barat, yaitu Kabupaten Ciamis, Kabupaten Tasikmalaya, Kota Banjar dan Kota Tasikmalaya.

Di Kabupaten Tasikmalaya terdapat 5 (lima) kecamatan yang masuk wilayah DAS Ciseel, sedangkan Kota Tasikmalaya terdapat 2 (dua) kecamatan yang masuk wilayah DAS Ciseel. Di Kabupaten Ciamis, DAS Ciseel meliputi 10 kecamatan, sedangkan Kota Banjar meliputi 2 (dua) kecamatan.

a. Kepadatan geografis DAS Ciseel

Gambar 13 A menunjukkan tentang sebaran spasial kepadatan geografis pada DAS Ciseel dalam kisaran range. Semakin tinggi nilai range menunjukkan kepadatan geografis wilayah tersebut makin tinggi. Kepadatan geografis tertinggi untuk wilayah DAS Ciseel berada pada wilayah Kota Tasikmalaya.

b. Sex rasio penduduk DAS Ciseel

Peta sebaran sex rasio dalam bentuk dot matrik (Gambar 13 B) menunjukkan bahwa semakin besar dot, semakin besar pula nilai sex rasio. Pada DAS Ciseel sebaran sex rasio yang mempunyai nilai range besar tersebar pada wilayah DAS yang terdapat pada wilayah Tasikmalya dan Banjar.

\section{c. Kepadatan agraris DAS Ciseel}

Berdasarkan peta kepadatan agraris (Gambar 13 C) DAS Ciseel, diketahui bahwa hampir sebagian besar wilayah DAS mempunyai tingkat kepadatan sedang. Untuk wilayah DAS yang mempunyai tingkat kepadatan tinggi berada disekitar hilir tepatnya di wilayah administrasi Ciamis. Hal ini menunjukkan bahwa DAS Ciseel mempunyai tingkat tekanan penduduk yang rendah terhadap lahan pertanian.

\section{d. Sebaran tenaga kerja DAS Ciseel}

Berdasarkan Gambar 13 D diketahui bahwa pada DAS Ciseel tenaga kerja tersebar merata disetiap wilayah DAS. Penumpukan tenaga kerja terbesar berada disekitar wilayah Kota Tasikmalaya dan Kota Banjar.

e. Sebaran ketergantungan terhadap lahan pertanian DAS Ciseel

Gambar 13 E menunjukkan peta ketergantungan terahadap lahan di DAS Ciseel. Sebaran nilai ini berada pada kisaran kurang dari $50 \%$, artinya berada pada kriteria rendah. Sebaran ketergantungan terhadap lahan pertanian untuk wilayah Kabupaten Tasikmalaya yang berada di wilayah DAS Ciseel secara keseluruhan mempunyai nilai kisaran tinggi. 


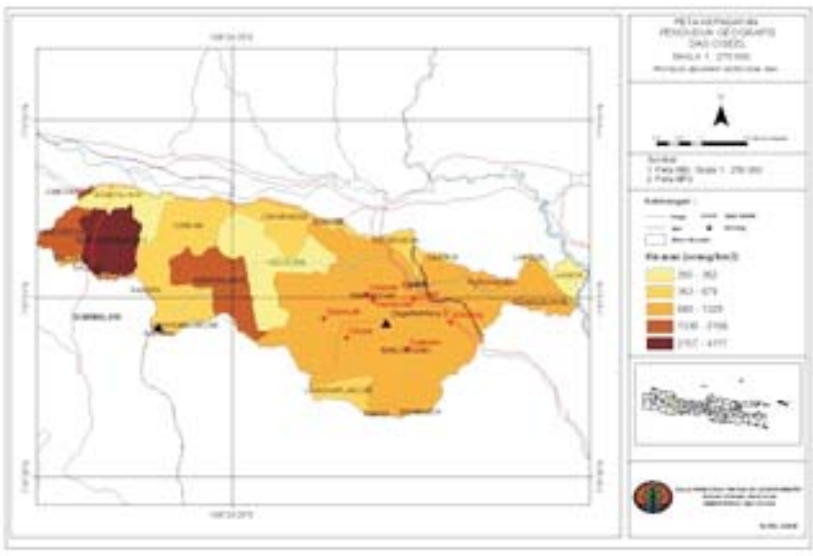

(A)

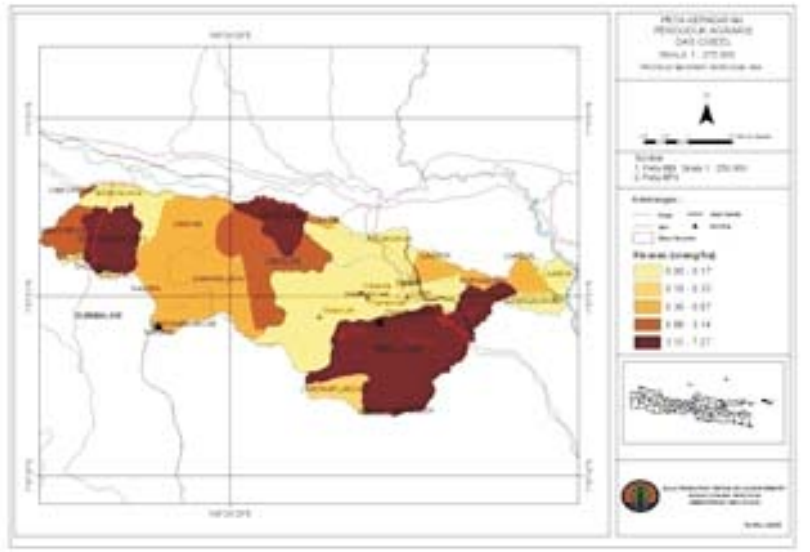

(C)

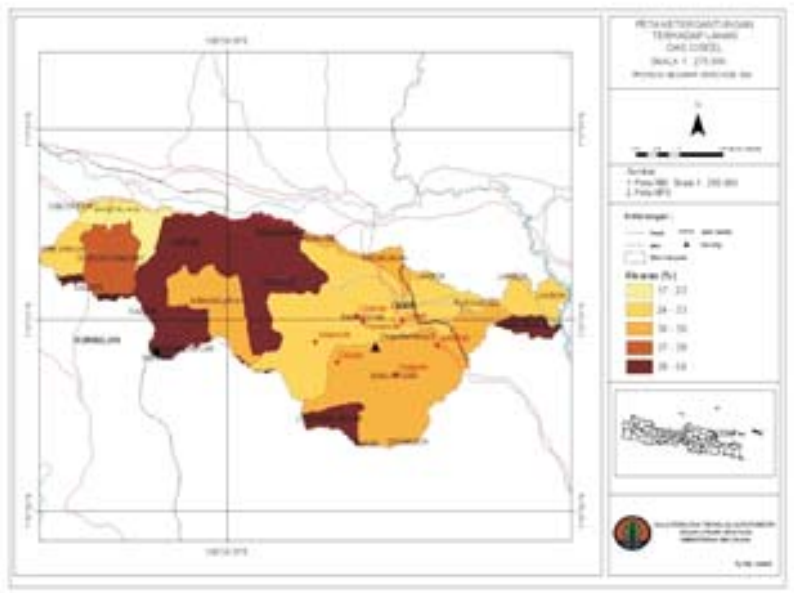

(E)

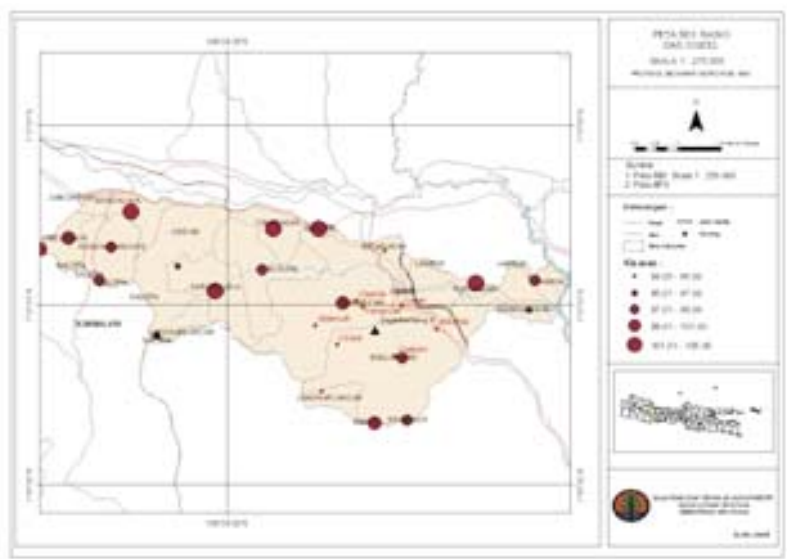

(B)

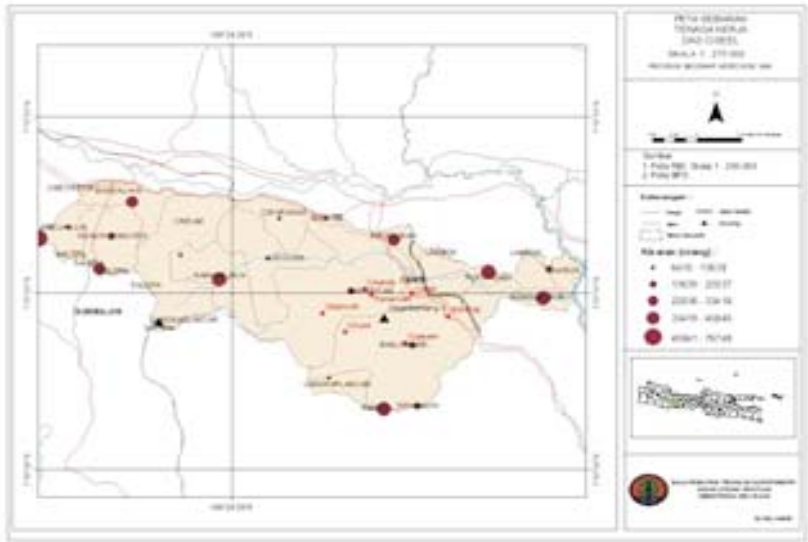

(D)

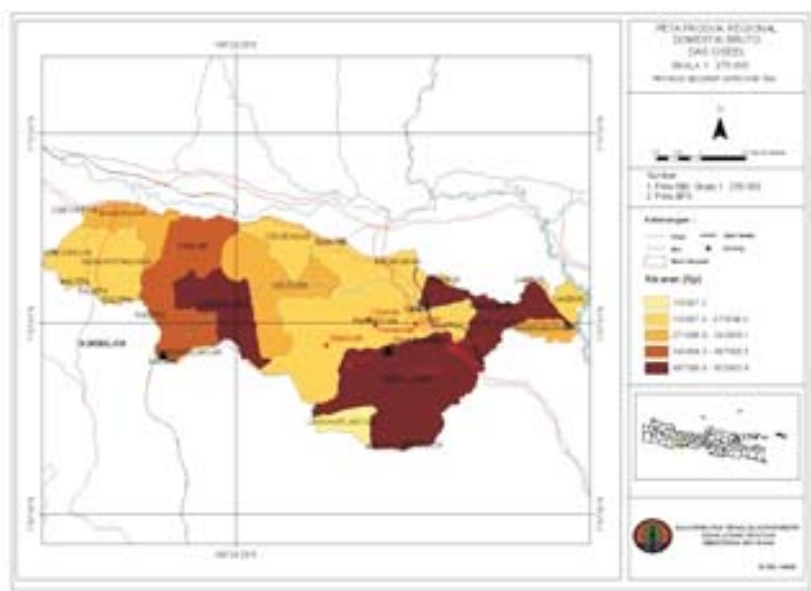

(F)

Gambar 13. DAS Ciseel(A) Peta sebaran kisaran kepadatan geografis; (B) Peta sebaran range rasio jenis kelamin; (C) Peta sebaran kepadatan agraris; (D) Peta sebaran tenaga kerja; (E) Peta sebaran ketergantungan terhadap lahan; (F) Peta sebaran pendapatan

Figure13. The Ciseel watershed (A) Distribution range of Geographic density; (B) Distribution range of sex ratios; (C) Distribution of Agricultural density; (D) Map of the Labor distribution; (E) Map of reliance on land distribution; (F) Map of income distribution 
f. Sebaran Pendapatan Regional Domestic Bruto (PRDB) DAS Ciseel

Nilai pendapatan suatu wilayah administrasi yang mencerminkan pendapatan pada suatu DAS, pada penelitian ini digambarkan secara range pada Gambar 13 F. Terlihat pada grafik bahwa pendapatan tertinggi berada disekitar wilayah DAS Ciseel bagian hilir, tepatnya di Kabupaten Banjar dan Ciamis. Secara umum hasil perhitungan tingkat pendapatan berada pada kriteria rendah yakni lebih kecil dari pendapatan masing-masing kabupaten.

\section{Hubungan antara Lanskap Hutan dengan Kondisi Biofisik dan Sosial Ekonomi}

\section{DAS Citanduy Hulu}

Hasil analisis menggunakan model GWR untuk mengetahui keeratan hubungan masing-masing faktor biofisik dan sosial ekonomi dengan keberadaan hutan, dianalisa dengan bantuan software spasial statistik SAM versi 4. Nilai keeratan hubungan didekati dengan nilai korelasi dari model GWR masing-masing faktor (biofisik dan sosial ekonomi). Tabel 3 menunjukkan hasil

Tabel 3.Hasil nilai korelasi antara keberadaan hutan dengan faktor-faktor biofisik dan sosial ekonomi pada DAS Citanduy Hulu

Table 3. The results of the correlation presence of forest with biophysical and socio-economicfactors in the Citanduy Hulu watershed

\begin{tabular}{|c|c|c|c|c|}
\hline \multirow{3}{*}{ No. } & \multirow{3}{*}{$\begin{array}{l}\text { Faktor } \\
\text { (Factor) }\end{array}$} & \multicolumn{3}{|c|}{$\begin{array}{l}\text { Keberadaan Hutan } \\
\text { (Forest existence) }\end{array}$} \\
\hline & & \multicolumn{3}{|c|}{$\begin{array}{c}\text { Korelasi } \\
\text { (Correlation) }\end{array}$} \\
\hline & & $\begin{array}{l}\text { Kuat } \\
\text { (Strong) }\end{array}$ & $\begin{array}{l}\text { Sedang } \\
\text { (Medium) }\end{array}$ & $\begin{array}{c}\text { Rendah } \\
\text { (Low) }\end{array}$ \\
\hline \multicolumn{5}{|c|}{ Biofisik } \\
\hline 1 & Curah hujan & $\square$ & & \\
\hline 2 & Hujan maksimum & & & $\square$ \\
\hline 3 & evapotranspirasi aktual & & $\square$ & \\
\hline 4 & Kelerengan & $\square$ & & \\
\hline 5 & Batuan induk & & & $\square$ \\
\hline 6 & Kedalam solum tanah & & & $\square$ \\
\hline 7 & Batuan singkapan & & & $\square$ \\
\hline 8 & Drainase tanah & & & $\square$ \\
\hline 9 & Permiabilitas tanah & & $\square$ & \\
\hline 10 & Erodibilitas tanah & $\square$ & & \\
\hline 11 & Gradien DAS & & $\square$ & \\
\hline 12 & Kerapatan Drainase & $\square$ & & \\
\hline 13 & Rata-rata lereng & $\square$ & & \\
\hline \multicolumn{5}{|c|}{ Sosial ekonomi } \\
\hline 1 & Kepadatan geografis & & $\square$ & \\
\hline 2 & Kepadatan agraris & $\square$ & & \\
\hline 3 & Rasio penduduk & & & $\square$ \\
\hline 4 & Pengelompokan tenaga kerja & & & $\square$ \\
\hline 5 & Ketergantungan terhadap lahan & $\square$ & & \\
\hline 6 & Tingkat pendapatan & & & $\square$ \\
\hline $\begin{array}{l}\text { Sumber } \\
\text { Keteran }\end{array}$ & $\begin{aligned}(\text { exce }) \text { : hasil analisa } & \text { (analysis result) } \\
\text { (expation): } & - \text { Korelasi kuat }=r>0,5 \\
& - \text { Korelasi sedang }=r=0,5 \\
& - \text { Korelasi rendah }=r<0,5 \\
& - \text { Fungsi pembobot spasial } \mathrm{n}\end{aligned}$ & are dan $\mathrm{m}$ & tungkan $n$ & Kernel \\
\hline
\end{tabular}


analisa nilai korelasi masing-masing faktor biofisik dan sosial ekonomi.

Hasil analisis menunjukkan bahwa terdapat faktor-faktor biofisik dan sosial ekonomi yang mempunyai nilai korelasi kuat terhadap keberadaan hutan pada DAS Citanduy Hulu. Hal ini menunjukkan terdapat hubungan antara keberadaan hutan pada DAS dengan kondisi faktor biofisik (lingkungan) dan kondisi sosial ekonomi masyarakatnya. Sedangkan faktor-faktor biofisik dan sosial ekonomi yang mempunyai nilai korelasi kuat terhadap keberadaan hutan pada DAS
Citanduy Hulu adalah curah hujan, kelerengan, erodibilitas tanah ( nilai kepekaan tanah terhadap erosi), kerapatan drainase DAS, rata-rata lereng DAS, kepadatan agraris dan ketergantungan terhadap lahan.

\section{DAS Ciseel}

Analisis nilai korelasi model GWR menggunakan software spasial statistik SAM versi 4 ditujukan untuk mengetahui keeretan hubungan masing-masing faktor biofisik dan sosial ekonomi dengan keberadaan hutan, dimana hasilnya disajikan dalam Tabel 4.

Tabel 4. Hasil nilai korelasi antara keberadaan hutan dengan faktor-faktor biofisik pada DAS Ciseel Table 4. The results of the correlation presence of forest with biophysical factors in the Ciseel watershed

\begin{tabular}{|c|c|c|c|c|}
\hline \multirow{3}{*}{ No. } & \multirow{3}{*}{$\begin{array}{l}\text { Faktor } \\
\text { (Factors) }\end{array}$} & \multicolumn{3}{|c|}{$\begin{array}{l}\text { Keberadaan Hutan } \\
\text { (Forest existence) }\end{array}$} \\
\hline & & \multicolumn{3}{|c|}{$\begin{array}{c}\text { Korelasi } \\
\text { (Correlation) }\end{array}$} \\
\hline & & $\begin{array}{l}\text { Kuat } \\
\text { (Strong) }\end{array}$ & $\begin{array}{l}\text { Sedang } \\
\text { (Medium) }\end{array}$ & $\begin{array}{c}\text { Rendah } \\
\text { (Low) }\end{array}$ \\
\hline \multicolumn{5}{|l|}{ Biofisik } \\
\hline 1 & Curah hujan & $\square$ & & \\
\hline 2 & Hujan maksimum & & $\square$ & \\
\hline 3 & evapotranspirasi aktual & & $\square$ & \\
\hline 4 & Kelerengan & $\square$ & & \\
\hline 5 & Batuan induk & & & $\square$ \\
\hline 6 & Kedalam solum tanah & & & $\square$ \\
\hline 7 & Batuan singkapan & & & $\square$ \\
\hline 8 & Drainase tanah & & $\square$ & \\
\hline 9 & Permiabilitas tanah & & $\square$ & \\
\hline 10 & Erodibilitas tanah & $\square$ & & \\
\hline 11 & Gradien DAS & & $\square$ & \\
\hline 12 & Kerapatan Drainase & $\square$ & & \\
\hline 13 & Rata-rata lereng & $\square$ & & \\
\hline \multicolumn{5}{|c|}{ Sosial ekonomi } \\
\hline 1 & Kepadatan geografis & & $\square$ & \\
\hline 2 & Kepadatan agraris & $\square$ & & \\
\hline 3 & Rasio penduduk & & & $\square$ \\
\hline 4 & Pengelompokan tenaga kerja & & & $\square$ \\
\hline 5 & Ketergantungan terhadap lahan & $\square$ & & \\
\hline 6 & Tingkat pendapatan & & & $\square$ \\
\hline
\end{tabular}

Sumber (source): hasil analisa (analysis result)

Keterangan (explanation): - Korelasi kuat $=r>0,5$

- Korelasi sedang $=\mathrm{r}=0,5$

- Korelasi rendah $=\mathrm{r}<0,5$

- Fungsi pembobot spasial menggunakan Bi-square dan memperhitungkan nilai spasial Kernel 
Hasil analisis menunjukkan terdapat faktorfaktor biofisik dan sosial ekonomi yang mempunyai nilai korelasi yang kuat terhadap keberadaan hutan (nilai korelasi kuat) pada DAS Ciseel. Hal ini menunjukkan bahwa tidak hanya faktor biofisik (lingkungan) yang mempengaruhi keberadaan hutan pada suatu DAS, tetapi faktor sosial ekonomi masyarakat yang berada pada DAS tersebut juga bisa mempengaruhi keberadaan hutan, sedangkan faktor-faktor biofisik dan sosial ekonomi yang mempunyai korelasi kuat terhadap keberadaan hutan di DAS Ciseel adalah curah hujan, kelerengan, erodibilitas tanah (nilai kepekaan tanah terhadap erosi), kerapatan drainase DAS, rata-rata lereng DAS, kepadatan agraris dan ketergantungan terhadap lahan.

\section{KESIMPULAN DAN SARAN}

\section{A. Kesimpulan}

1. Terdapat hubungan yang erat antara keberadaan hutan pada suatu DAS dengan kondisi sosial ekonomi masyarakatnya dan kondisi biofisik (lingkungan). Hubungan tersebut dapat dibuktikan dengan menggunakan Metode Geographically Weighted Regression models (GWR).

2. Aplikasi metode GWR pada DAS berpasangan Citanduy Hulu dan DAS Ciseel menunjukkan bahwa keeratan hubungan antara faktor biofisik dan sosial ekonomi terhadap keberaadaan lanskap ditentukan oleh faktor curah hujan, kelerengan, kepekaan tanah terhadap erosi, kerapatan drainase DAS, rata-rata lereng DAS, kepadatan agraris dan ketegantungan terhadap lahan.

3. Rendahnya korelasi yang ditunjukkan melalui rasio penduduk, tenaga kerja dan tingkat pendapatan diduga merupakan konsekuensi dari keberadaan Kota Tasikmalaya dan Banjar sebagai outlet penyedia kesempatan kerja dan pendapatan bagi masyarakat di wilayah DAS Citandui Hulu dan DAS Ciseel.

\section{B. Saran}

Penentuan arahan spasial keberadaan hutan yang ditentukan oleh faktor biofisik (curah hujan, kelerengan dan jenis tanah) perlu ditinjau kembali dengan memasukkan faktor sosial ekonomi masyarakat dan faktor keberadaan DAS. Pertimbangan tersebut diperlukan agar rencana pembangunan kehutanan dalam melestarikan sumberdaya hutan dan air dilakukan sesuai dengan kenyataan lapangan,sehingga mendukung pengentasan kemiskinan serta meminimalkan konflik dengan masyarakat.

\section{DAFTAR PUSTAKA}

Arsyad, S. 2006. Konservasi Tanah dan Air. IPB Press. Bogor.

Becerra, E.H., 1995. Monitoring and Evaluation of watershed Management Project Achivements. FAO Conservation Guide 24. FAOUN. Rome.

Diaz, N. and Apostol, D. _-__ .Forest LandscapeAnalysis and Design.A Process for Developing andImplementing Land ManagementObjectives for Landscape Patterns.USDA Forest Service.Pacific Northwest Region.United State.

Fotheringham, A.S.,Charlton, M., and Brunsdon, C. 2002.Geographically Weighted Regression. ESRC National Centre for Research Methods.NCRM Methods Review Papers. [terhubung berkala]. http://ncg. nuim.ie/GWR. Html [11 Desember 2010]

Green, B.H., E.A. Simmons, and I. Woltjer. 1996. Landscape Conservation: Some Steps Towards Developing a New Conservation Dimension. A draft report of the IUCN-CESP Landscape Conservation Working Group. Dept. Agriculture, Horticulture and Environment, WyeCollege, Ashford, Kent, UK

Jennings, S., Jarvie, J. 2002. A Sourcebook for Landscape Analysis of High Conservation Value Forests.

Keputusan Presiden Republik Indonesia, 1990. Kepres No. 92 tentang Pengelolaan Kawasan Lindung. [terhubung berkala]. http://www. dephut.go.id/bksda. [11 november 2011].

Maryani, R. 2010. Manajemen Lanskap Hutan Berbasis Daerah aliran Sungai (DAS). Rencana Penelitian Integratif 2010 - 2014. Pusat Penelitian Sosial Ekonomi dan Kebijakan Kehutanan. Badan Penelitian dan 
Pengembangan Kehutanan. Kementerian Kehutanan. Bogor.

Paimin, Sukrisno dan Purwanto. 2006. Sidik Cepat Degradasi Sub Daerah Aliran Sungai. Puslit Hutan dan Konservasi Alam. Badan Penelitian dan Pengembangan. Departemen Kehutanan. Bogor.

Pawitan, H. 2004. Aplikasi Model erosi dalam Perpektif Pengelolaan Derah Aliran Sungai. I Prosiding Seminar Degradasi Lahan dan Hutan. Masyarakat Konservasi Tanah dan Air Indonesia. Universitas Gadjah Mada dan Departemen Kehutanan.
Surat Keputusan Menteri Pertanian, 1980, Nomer $837 / \mathrm{kpts} / \mathrm{Um} / 11 / 1980$ tentang Kriteria dan Tata Cara Penetapan Hutan Lindung. [terhubung berkala]. http://www.deptan. go.id/..... [11 November 2011]

Thiago F. Rangel, Jose,A. F. Diniz-Filho and Luis, M. B. 2010. SAM: a comprehensive application for Spatial Analysis in Macroecology. Journal compilation of Ecography. 